\title{
Postnatal Construction of Neural Circuitry in the Mouse Olfactory Bulb
}

\author{
Scott L. Pomeroy, ${ }^{1.2}$ Anthony-Samuel LaMantia, ${ }^{1}$ and Dale Purves ${ }^{1}$ \\ 'Department of Anatomy and Neurobiology, and 'Department of Pediatrics, Washington University School of Medicine, \\ St. Louis, Missouri 63110
}

\begin{abstract}
We have undertaken a quantitative analysis of the mouse olfactory bulb to address several major questions concerning the development of neural circuitry in the postnatal mammalian brain. These are: (1) To what degree are new elements and circuits added during maturation? (2) How long do such processes go on? and (3) Does postnatal development involve a net addition of circuits and their constituent elements, or is there elimination of some portion of an initial surfeit?
\end{abstract}

Using male mice of known age, weight, and length, we measured the overall size of the bulb, the numbers of processing units (glomeruli) within the bulb, the extent and complexity of postsynaptic dendrites within the glomeruli, and the number of synapses in different regions of the bulb. Between birth and the time mice reach sexual maturity at 67 weeks of age, the bulb increases in size by a factor of 8 , the number of glomeruli by a factor of 4-5, the length of mitral cell dendritic branches by a factor of 11 , and the number of glomerular and extraglomerular synapses by factors of 90 and 170, respectively. Each of these parameters increases steadily from birth, in concert with the enlargement of the olfactory mucosa, the overall growth of the brain, and indeed, of the entire animal. We found no evidence of an initial surfeit of processing units, dendritic branches, or synapses. Further elaboration of neural circuitry by each of these measures is also apparent from the time of sexual maturity until the animals reach their full adult size at about 10-12 weeks of age.

The developmental strategy in this part of the mouse brain evidently involves prolonged construction that persists until the growth of the body is complete. This ongoing elaboration of neural circuitry in the postnatal mammalian brain may be relevant to understanding a number of unexplained developmental phenomena, including critical periods, the ability of the juvenile brain to recover from injuries that would cause severe and permanent deficits in older animals, and the special ability of the maturing brain to encode large amounts of new information.

Received Nov. 20, 1989; revised Dec. 28, 1989; accepted Dec. 29, 1989.

We are especially grateful to Pat Newton for her steadfast assistance in many phases of this project. Thanks are also due to Ladan Hedayati for extensive help with computer graphics and statistics. Dot Dill for preparing electron microscopic sections, and Anna Tourville for her assistance. Valuable help was also provided by Harriett Purves. Finally, we thank Harold Burton, Jeff Lichtman, and Josh Sanes for comments on the manuscript.

Correspondence should be addressed to Dr. Dale Purves at his present address: Department of Neurobiology, Box 3209, Duke University, Durham, NC 27760.

Copyright (C) 1990 Society for Neuroscience 0270-6474/90/061952-15\$02.00/0
An obvious fact of neural development in mammals is the increasing size of the brain during postnatal maturation (Copoletta and Wolbach, 1933; Pakkenberg and Voigt, 1964; Dekaban and Sadowsky, 1978). Much recent work, however, has underscored the regressive nature of neural development, emphasizing the loss of neural circuitry as a fundamental theme (reviewed in Cowan et al., 1984; Purves and Lichtman, 1980, 1985; Purves, 1988). The prevalence and importance of regressive phenomena in various parts of the developing nervous system are not in dispute. Nevertheless, one wonders how a decreasing complement of neurons, axons, dendrites, and synapses can lead to an overall increase in brain size. Prolonged postnatal brain growth in mammals might simply reflect an enlargement of surviving neurons and an increase in the number of non-neuronal cells without significant changes in neural circuitry. Conversely, the ongoing growth of the brain in postnatal life might indicate a progressive increase in the number and complexity of neuronal circuits (broadly defined here as groups of richly interconnected neurons that serve a common function).

The resolution of this issue is pertinent to several fundamental questions in neurobiology, including the basis of critical periods, the response of the CNS to injury at different ages, and the remarkable ability of the juvenile brain to encode large amounts of new information. Understanding the cellular basis of postnatal brain growth is also relevant to evaluating the merits of several popular theories of neural development based on initial redundancy and subsequent selection (Changeux et al., 1973; Young, 1973, 1979; Changeux and Danchin, 1976; Changeux, 1985; see also Edelman, 1978, 1987), an idea sometimes referred to as "neural Darwinism."

To address these concerns, we have examined the development of the mouse olfactory bulb, a well-defined part of the brain in which quantitative analysis can be done completely and reliably. In spite of some peculiarities of the olfactory system (see Discussion), the olfactory bulb has several features that recommend it for this analysis. First, it is small and circumscribed. Second, the bulb is clearly laminated and comprises only 4 basic neuronal types. Third, and perhaps most important, the major processing circuits of the olfactory bulb, the glomeruli, are anatomically distinct and can therefore be counted both in histological preparations (Meisami, 1979; Meisami and Safari, 1981; Royet et al., 1988) and by direct monitoring in the living animal (LaMantia and Purves, 1989). Indeed, an important motivation for the present work was the earlier finding that the number of glomeruli increases for at least the first several postnatal weeks in rodents (Meisami, 1979; Meisami and Safari, 1981; LaMantia and Purves, 1989), a process that occurs with- 
out apparent deletions from the initial population (LaMantia and Purves, 1989).

The results of our present analysis of the numbers of circuits, neuronal branches, and synapses in the olfactory bulb as a function of postnatal age indicate that this region of the mammalian CNS is actually constructed over at least the first $21 / 2-3$ months of the mouse's life. For the strain of mouse we used, this period extends well beyond the time of sexual maturity (6-7 weeks) and represents a substantial fraction of the animal's lifetime (about $10 \%$ ). On the basis of this evidence, we suggest a constructionist theory of postnatal brain development in mammals, arguing that the ongoing elaboration of neural circuitry during maturation provides the cellular substrate for several important developmental phenomena.

Some of this work has been reported in abstract form (Pomeroy et al., 1989).

\section{Materials and Methods}

Animals and tissue preparation. Timed pregnancies were used to generate litters of known age in a breeding colony of CF1 mice. On average, gestation in this strain is $20 \mathrm{~d}$ (range 18-21 d). Litters varied in size from 4 to 12 pups, with an average of 8 pups/litter; only males were examined to avoid any confounding influence of sexual dimorphism. Pups were housed with their mother until weaning at 3 weeks of age, at which time the animals were separated according to sex. Littermates were housed together, usually 3-4 mice per cage.

At appropriate ages from birth to 24 weeks, mice were weighed and their length (nose to base of tail) measured to the nearest millimeter. The mice were killed with an overdose of Nembutal $(250 \mathrm{mg} / \mathrm{kg}, \mathrm{i}$.p.) and perfused transcardially with $0.9 \% \mathrm{NaCl}$ in $0.1 \mathrm{M} \mathrm{PO}_{4}$ buffer (pH $7.4 ; 37^{\circ} \mathrm{C}$ ). This was followed by perfusion with a solution of $1.25 \%$ paraformaldehyde, $1.25 \%$ glutaraldehyde in the same buffer saturated with $\mathrm{CaCl}_{2}$, and subsequently by an ice-cold solution of $2.5 \%$ paraformaldehyde, $2.5 \%$ glutaraldehyde. The brains were removed and postfixed overnight in $2.5 \%$ aldehyde solution. The following day the tissue was rinsed repeatedly with $0.1 \mathrm{M}$ phosphate buffer. At this point, each brain was carefully blotted and weighed, and a working photograph made from which measurements could be taken. The brains were then immersed overnight in a solution of $0.4 \%$ gelatin, $30 \%$ albumin, $15 \%$ sucrose. Finally, the entire brain was embedded in gelatin/albumin, polymerized by the addition of $3 \%$ glutaraldehyde, and the olfactory bulbs sectioned coronally at $50 \mu \mathrm{m}$ with a Lancer Vibratome. We chose Vibratome sections because light and electron microscopical analysis can be carried out on the same tissue, thus avoiding the problem of differential shrinkage.

Alternate sections were mounted on gelatin-coated slides and stained with cresyl violet for light microscopy. Every 20 th section was postfixed with a $2 \%$ solution of osmium tetroxide, stained en bloc with $2 \%$ uranyl acetate, and infiltrated with a mixture of epon and araldite resins. The thick sections were embedded flat between sheets of acetate film and recut on an ultramicrotome (see below). Thin sections of the olfactory bulb were mounted on formvar-covered slot grids, stabilized by carbon coating, and studied by transmission electron microscopy using a JEM 1200EX.

Light microscopic analysis of the olfactory mucosa. A separate series of animals was prepared to examine the olfactory mucosa from birth through maturity. These animals were perfused with PBS followed by a solution of $4 \%$ paraformaldehyde, $4 \%$ glutaraldehyde in phosphate buffer. The entire upper portion of the snout, from the tip of the nose to the anterior pole of the cortex, was removed; the overlying skin and connective tissue were dissected away, and the tissue postfixed overnight. After decalcification with $0.1 \mathrm{~m}$ solution of EDTA $(\mathrm{pH} \mathrm{7.0)}$ at $4^{\circ} \mathrm{C}$ for $2-4 \mathrm{~d}$, the specimens were immersed in a solution of $30 \%$ sucrose in $0.1 \mathrm{M}$ phosphate buffer until they sank (approximately $8 \mathrm{hr}$ ). The block was then embedded in gelatin/albumin, frozen rapidly, and sectioned at $15 \mu \mathrm{m}$ in a cryostat. Every 20th section was mounted on gelatin-coated slides and stained with cresyl violet. The total surface area of the olfactory mucosa was calculated from measurements of camera lucida drawings of the sections using a procedure similar to that described by Meisami (1989).

Light microscopic analysis of the olfactory bulb. Serially mounted, cresyl violet-staincd sections through the olfactory bulb were drawn individually with a camera lucida at a final magnification of $60 \times$. The glomeruli and the boundaries of the glomerular, mitral cell, and granule cell layers were included in the tracings. The area of each section was measured by tracing its outline on a digitizing tablet and multiplying the number of pixels contained within the tracing by the area per pixel. The volume of each section was then calculated by multiplying the area by the section thickness; the volume of each skipped section was estimated by calculating the average area of the 2 adjacent sections and multiplying by section thickness. Finally, the overall volume of each of the olfactory bulbs was determined by adding these volumes.

The total number of the olfactory glomeruli was counted in the camera lucida tracings, and the actual number of glomeruli estimated by correcting for double counts (Abercrombie, 1946) and multiplying by 2 to compensate for the skipped sections. The average cross-sectional area of 200 glomeruli in 2-3 adjacent sections taken from the midregion of the olfactory bulbs of each animal was also measured on a digitizing tablet. We chose the midregion because average glomerular size is somewhat smaller at the extreme anterior or posterior poles of the bulb (Royet et al., 1988). Glomerular diameter, taken as the diameter of a circle equivalent to the measured cross-sectional area, was calculated using morphometric programs included in the IMAGR system written by $\mathbf{J}$. Voyvodic (Voyvodic, 1986; Purves and Voyvodic, 1987). It should be noted that these measured mean diameters underestimate the actual mean diameter because of glomerular fragments that do not include the equator. This deficiency, in turn, causes some underestimation of the calculated postnatal increase in glomerular numbers that we report (because the actual diameters of the larger glomeruli in older animals will be morc scriously underestimated than glomerular diameters in younger animals).

Light microscopic analysis of dendritic complexity. The dendritic arborizations of mitral cells were studied by retrograde staining with $1,1^{\prime}$ dioctadecyl-3,3,3',3'-tetramethylindo-carbocyanine perchlorate; diI-c $\mathrm{c}_{18}$ (3) (DiI) in fixed tissue. Animals were perfused through the heart with PBS followed by $10 \%$ formaldehyde in the same buffer. The brains were removed and a small crystal of DiI placed on each of the lateral olfactory tracts. The tissue was then incubated in fixative at $40^{\circ} \mathrm{C}$ for $2-6$ weeks, longer incubation intervals being necessary for satisfactory labeling in older animals. The bulbs were embedded in $10 \%$ agar and $8 \%$ sucrose in distilled water, sectioned coronally at $75-100 \mu \mathrm{m}$ on the Vibratome, and examined with an epifluorescence microscope (530-560 nm emission filter; $580 \mathrm{~nm}$ barrier). The perimeters of labeled apical dendritic tufts were traced with a camera lucida at a final magnification of $400 \times$; the areas of the tufts were measured with a digitizing tablet, and the diameters of equivalent circles determined. Confocal images of a smaller sample of apical dendrites were obtained with a Lasersharp 500 system (BIORAD). The confocal light source was a $25 \mathrm{~mW}$ argon ion laser with an exciting wavelength of $514 \mathrm{~nm}$ and a high-pass $550 \mathrm{~nm}$ barrier filter. A series of focal planes at $0.25 \mu \mathrm{m}$ intervals through the entire depth of the apical dendrite was imaged using a water immersion objective (Leitz $50 \times ; \mathrm{NA}=1.0$ ) and stored on an optical disk for later analysis. Several of these focal planes were overlaid to create a series of composite optical sections of the dendritic tuft. The number of branch points was then counted in each composite optical section, and the length of all dendritic branches measured with the Lasersharp morphometric system. Overall values for each dendritic tuft were obtained by summing the measurements from the composite sets of focal planes.

Electron microscopic analysis of synaptic density. To determine the number of synapses at various ages, a flat-embedded $50 \mu \mathrm{m}$-thick section was selected from the midportion of each bulb and resectioned at $1 \mu \mathrm{m}$ with a glass knife. When a semithin section that included a substantial length of the glomerular and external plexiform layers appeared, the block was thin-sectioned with a diamond knife to obtain silver-gold sections for electron microscopic analysis. Thin sections were placed on formvar-coated, carbon-stabilized slot grids and stained with lead citrate and uranyl acetate.

In each specimen, 2 glomeruli were sampled by photographing 5 fields at a primary magnification of $10,000 \times$, one at each end of 2 orthogonal diameters through the glomerulus, and one at the intersection of the diameters. All electron micrographs were printed at a final magnification of $40,000 \times$; a calibration grid photographed at the end of each electron microscopy session was used to verify the enlargement. Synaptic density was estimated in the electron micrographs by counting the number of synaptic specializations (vesicles associated with pre- and postsynaptic densities) in a $50 \mu \mathrm{m}^{2}$ field defined by a frame of standard shape and 


\section{A}

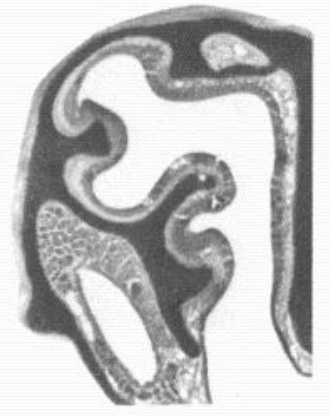

birth

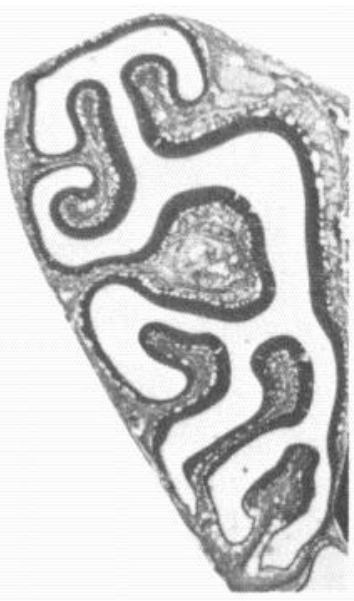

2 weeks

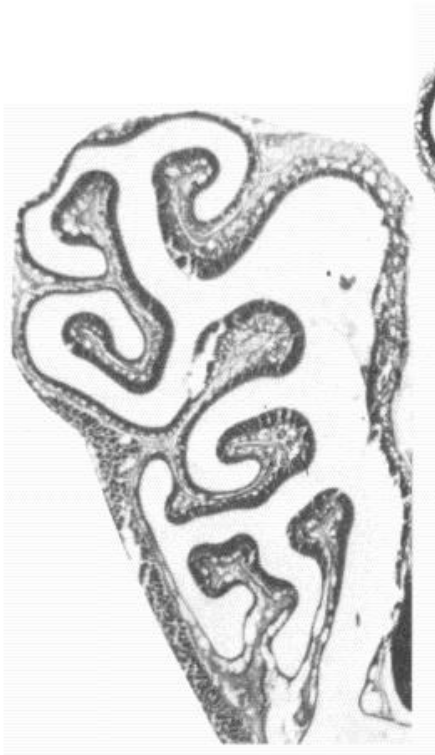

6 weeks

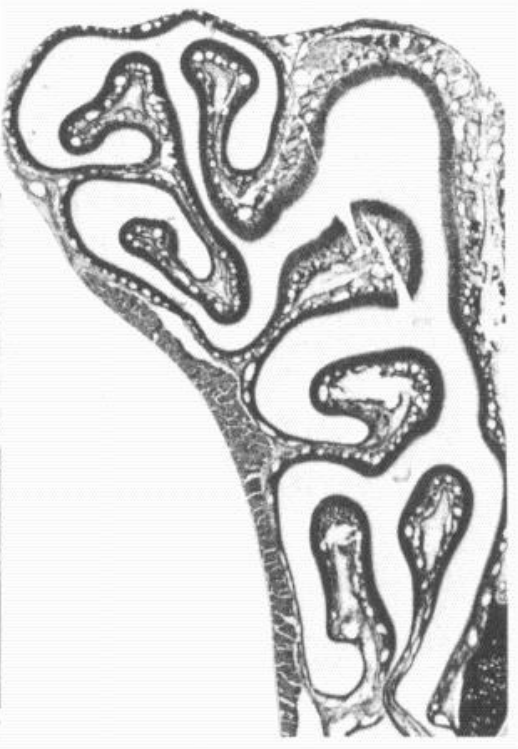

24 weeks

$1 \mathrm{~mm}$

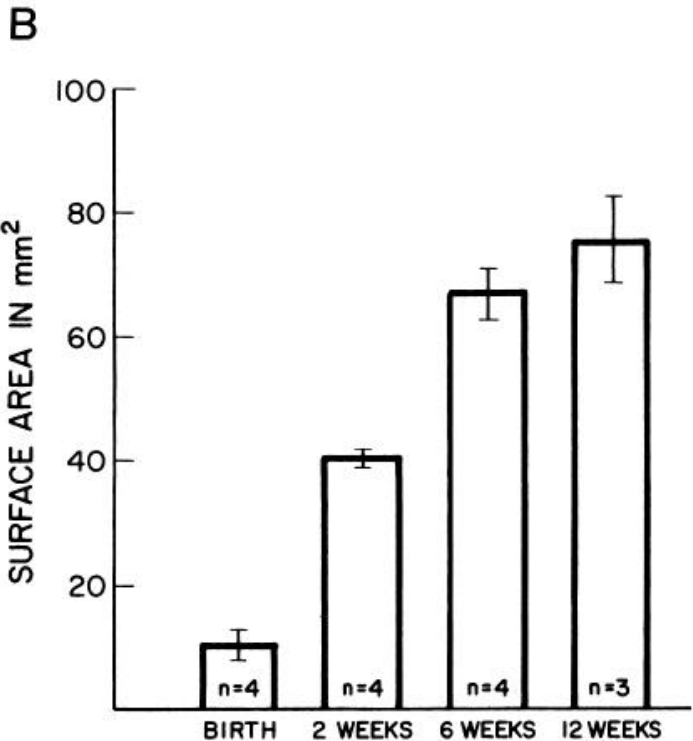

Figure 1. Development of the olfactory mucosa in CF1 male mice. A, Representative cross-sections through approximately the same rostrocaudal level of the right nasal cavity at the ages indicated; dorsal aspect is uppermost. The olfactory mucosa, which lines most of the nasal cavity at this level, can be distinguished from the thinner cuboidal epithelium of the respiratory mucosa that lines the remainder of the nasal cavity. $B$, Surface area of the olfactory mucosa as a function of age.

orientation. Only synaptic specializations that intersected 2 of the 4 borders of the frame (and 2 of the 4 corners) were included to correct for errors introduced by profiles that extended beyond the limits of the frame (Gunderson, 1977). Synaptic density per unit area of glomerular neuropil was then calculated as the mean number of synapses counted in each set of micrographs. The length of each synaptic apposition was also measured using a digitizing tablet.

In order to evaluate synaptic density in a part of the olfactory bulb devoid of primary afferent terminals, a similar analysis was made in the external plexiform layer. For this purpose, the external plexiform layer in each animal was sampled in 3 vertical cores, divided into upper, middle, and lower thirds. A single field was photographed in each region, providing a total of $9-50 \mu \mathrm{m}^{2}$ fields per bulb. As in the analysis of synaptic density within glomeruli, each micrograph was obtained at a primary magnification of $10,000 \times$ and printed at a final magnification of $40,000 \times$; the micrographs were analyzed as described above. No attempt was made to distinguish synaptic types in either the glomerular or the external plexiform layers, although synapses in these regions have been well categorized (e.g., Pinching and Powell, 1971).

To estimate the number of synapses per unit volume, the synaptic density per unit area was divided by the mean tangent diameter of synaptic specializations measured in each animal (Colonnier and Beau- 

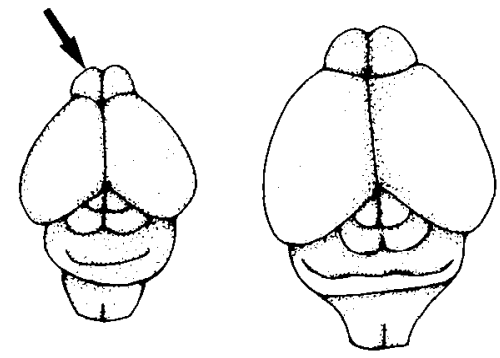

Newborn
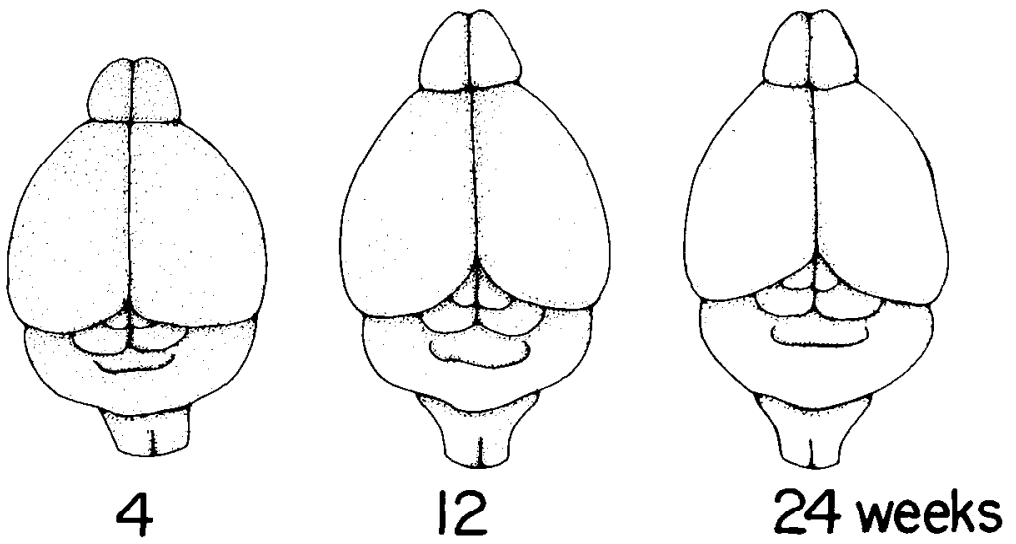

$10 \mathrm{~mm}$

Figure 2. Tracings of the developing mouse brain made from working photographs; each brain was taken from an animal near the average size for the ages illustrated. At birth, the mean weight of the entire brain of a CFI male mouse is $120 \pm 17 \mathrm{mg}(n=11 ; \pm \mathrm{SEM})$. By 12 weeks of age the brain weighs $470 \pm 30 \mathrm{mg}(n=16)$ and increases little, if at all, in size between 12 and 24 weeks. The postnatal enlargement of the olfactory bulbs (arrow) parallels the overall growth of the brain.

lieu, 1985). The standard deviation of the length of synaptic specializations was usually less than $\pm 20 \%$ of the mean for each sample; therefore, the mean tangent diameter was computed by multiplying the measured synaptic length by $4 / \pi$.

\section{Results}

Postnatal growth of the mouse

At birth, CFl male micc weigh $1.4 \mathrm{gm}$, on avcrage, and mcasure $3 \mathrm{~cm}$ in length. Weight and length increase rapidly for the first 6 weeks of life and then more slowly, with mature values being attained at about 10-12 weeks of age. At maturity, the average CF1 male mouse weighs $28 \mathrm{gm}$ and measures $10 \mathrm{~cm}$ from nose to base of tail. Little change in body size occurs between 12 weeks $(28.0 \mathrm{gm} \pm 0.5, n=18, \pm \mathrm{SEM})$ and 24 weeks $(30.4 \mathrm{gm}$ $\pm 0.5, n=17$ ), the oldest animals studied in this series. The attainment of adult body size postdates the time of sexual maturity for malc mice, considered to be 6-7 wecks of age for this strain (information supplied by the commercial breeder of our CFl strain, Harlan Sprague-Dawley, Inc.; our own experience indicates that males as young as 4 weeks may be fertile). The lifespan of CF1 mice is about 2 years.

In the context of the present study, the most pertinent aspect of somatic growth is that of the nose. The nasal passage at all ages is a highly convoluted structure (Fig. $1 A$ ) which begins at the nares, continues through the snout, and ends beneath the olfactory bulbs. At birth the total surface area of the olfactory mucosa is about $10 \mathrm{~mm}^{2}$; the postnatal growth of the mucosa is progressive, with values of approximately $70-100 \mathrm{~mm}^{2}$ being reached at 10-12 weeks of age (Fig. 1B).

\section{Postnatal growth of the olfactory bulb}

The olfactory bulbs grow steadily in size from birth to maturity, in parallel with the overall growth of the brain (Figs. 2, 3). Thus, the length of the olfactory bulb increases from about $1.0 \mathrm{~mm}$ at birth to $3.1 \mathrm{~mm}$ at 10-12 weeks of age, while the volume of bulb increases from about $0.8 \mathrm{~mm}^{3}$ to $8.4 \mathrm{~mm}^{3}$ over this period. As in the case of body and brain size, olfactory bulb size changes little, if at all, between 12 and 24 weeks of age.

\section{Postnatal increase in the number of olfactory glomeruli}

Counts of olfactory glomeruli in Nissl-stained serial sections of the olfactory bulbs of animals at different ages show a progressive increase in the number of these anatomically distinguishable circuits from birth to maturity (Fig. 4). In neonatal animals, the number of glomeruli counted in camera lucida drawings of every other section through the bulb is about 300 ; by 12 weeks of age this value increases to about 1800 , the adult complement. Corrected values (see Materials and Methods) are 410 glomeruli at birth and 1710 at maturity. A similar increase in glomerular number during development has been reported in the rat (Meisami, 1979; Meisami and Safari, 1981). Figure 5 shows representative bulbs at different ages reconstructed by computer graphics to illustrate the addition of new glomeruli in relation to the overall growth of this part of the brain.

In an earlier study in which we monitored the addition of glomeruli in the brains of individual mice over several weeks (LaMantia and Purves, 1989), it was apparent that the glomeruli present at birth are maintained without any loss from the initial population. Thus the increase with age determined from histological sections represents a steady addition of new units.

\section{Postnatal growth of olfactory glomeruli}

The overall growth of the bulbs is reflected in obvious changes in the size of each of the 5 layers of bulb [the glomerular layer, the external plexiform layer, the mitral cell layer, the internal plexiform layer, and the granule cell layer (Fig. 6)]. In particular, the thickness of the glomerular and external plexiform layers increases markedly during postnatal development. The mean cross-sectional area of glomeruli also increases, from $800 \mu \mathrm{m}^{2}$ at birth to about $4300 \mu \mathrm{m}^{2}$ in maturity (Fig. $7 \mathrm{~A}$; see also Fig. 5). The mean diameter of glomeruli calculated from these areal measurements is $32 \mu \mathrm{m}$ at birth and $68 \mu \mathrm{m}$ at approximately 10-12 weeks of age (Fig. $7 B$; see also Meisami and Shafa, 1977). Based on these measurements, mean glomerular volume increases from $15,000 \mu \mathrm{m}^{3}$ at birth to $167,000 \mu \mathrm{m}^{3}$ by $10-12$ weeks of age. 
A

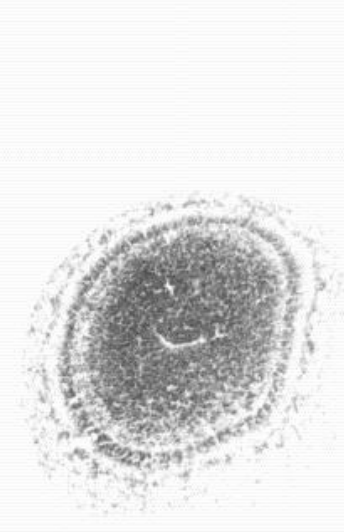

birth

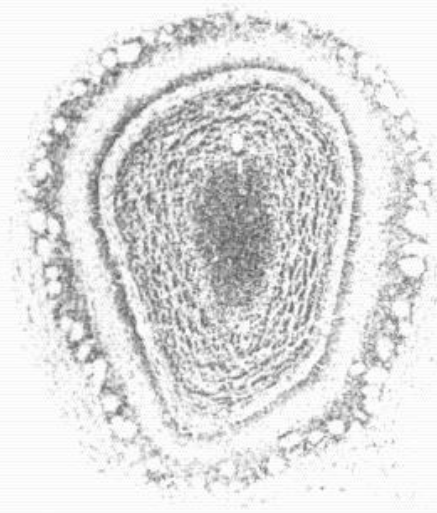

1 week

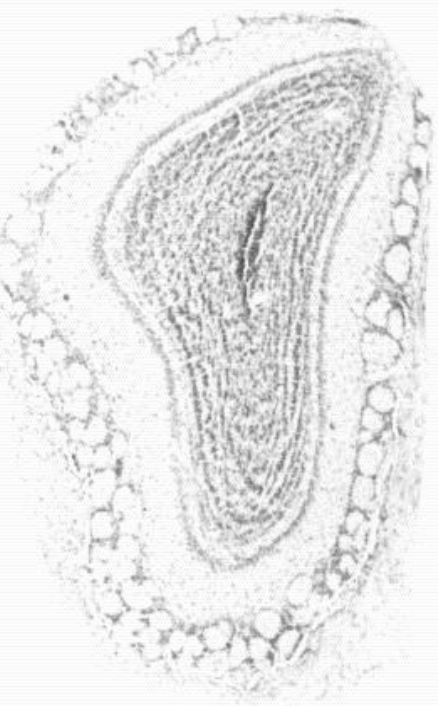

4 weeks

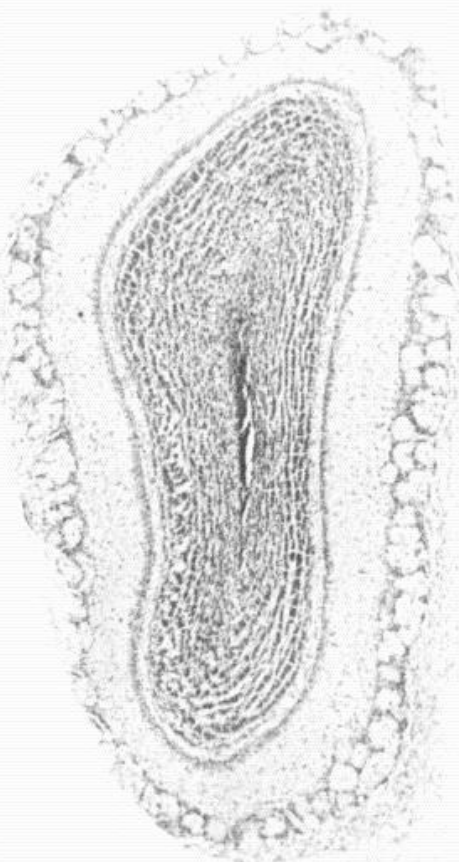

12 weeks

$0.5 \mathrm{~mm}$

B

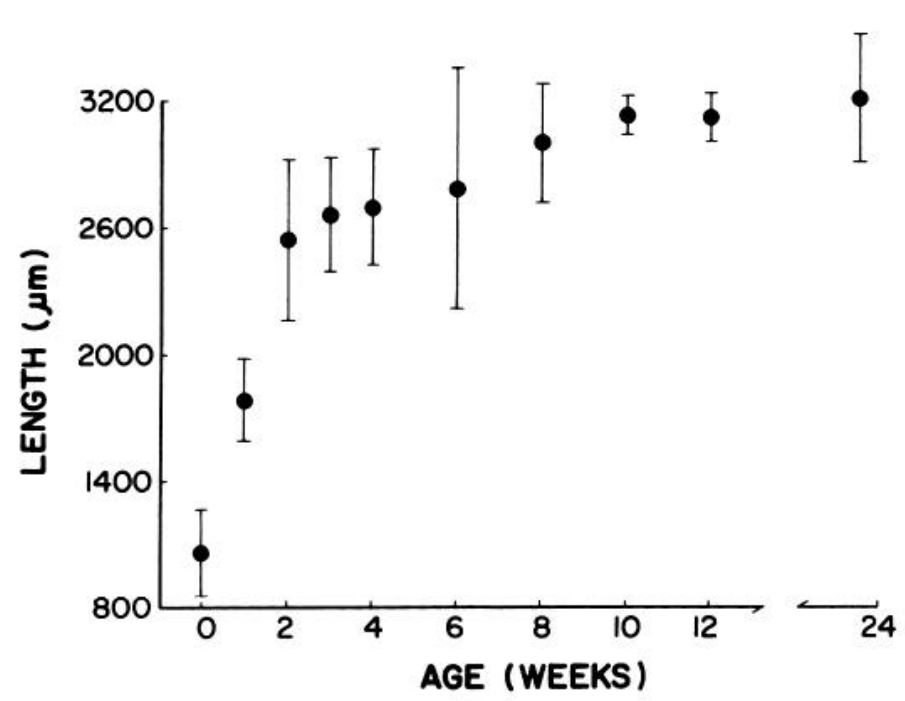

C

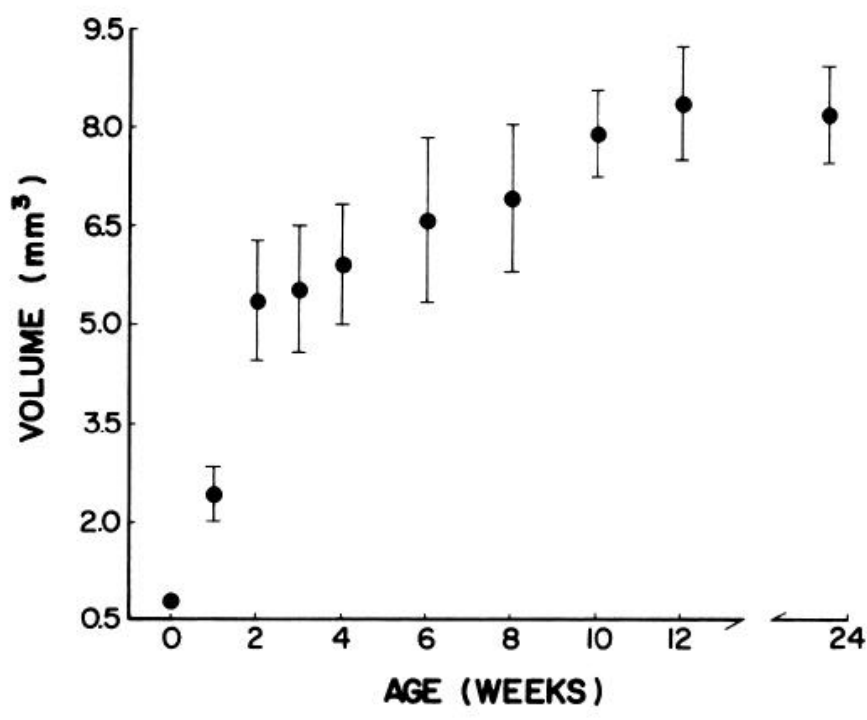

Figure 3. Growth of the olfactory bulbs of CF1 male mice from birth to 24 weeks of age. A, Photomicrographs of frontal (coronal) sections of the developing mouse olfactory bulb stained with cresyl violet. The sections show the midregion of the right bulb from animals whose size is near the average for their age. $B$, The length of the olfactory bulbs, determined from the number of serial sections of known thickness necessary to traverse them. The posterior limit of each bulb was defined as the last section in which glomeruli appeared. Each point represents the mean of measurements of 10 olfactory bulbs in at least 5 different animals at each age; error bars show the standard deviation. $C$, Volume of the olfactory bulb as a function of age, determined by calculation from tracings of serial sections (see Materials and Methods). Attainment of adult values at 10-12 weeks parallels the growth of the brain as a whole (Fig. 2). This and subsequent figures include roughly equal numbers of determinations from the right and left bulbs; no significant differences were observed between the 2 sides. 


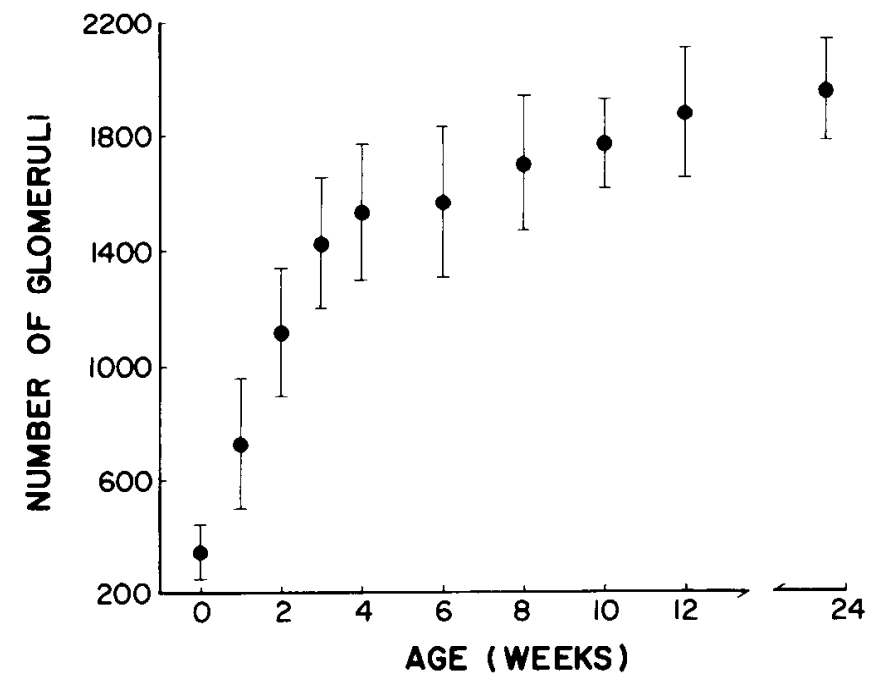

Figure 4. Number of olfactory glomeruli counted in the developing bulbs of CFl male mice from birth to 24 weeks of age. Each point represents the mean of counts in 10 bulbs from at least 5 different animals; error bars show the standard deviation. Values shown are uncorrected counts taken directly from camera lucida tracings; corrected values are similar (see text).

\section{Size and complexity of mitral cell dendrites}

The growth of mitral cell dendrites was estimated from camera lucida tracings of the apical dendrites after retrograde labeling from the lateral olfactory tract with DiI (Figs. 8-10). The size of the apical dendritic tuft, corresponding to the portion of the mitral cell dendrite within a glomerulus, was measured for each of 46-70 mitral cells at various ages by drawing a perimeter around its outermost branches. The camera lucida drawings were then traced on a digitizing tablet. The average diameter of the apical dendritic tuft measured in this way increases about 2-3-fold during the first 10-12 weeks of postnatal life (Fig. 9).

To obtain a more precise picture of the growth of dendritic branches within glomeruli, 3 representative apical dendritic tufts were selected at each age for detailed measurement (Fig. 10). A series of focal planes through the entire depth of the dendritic tuft, each $0.25 \mu \mathrm{m}$ apart, was obtained by means of confocal microscopy. Measurements made of these images (see Table 1) showed that the mean number of dendritic branch points within glomeruli increases from 37 at birth to 272 at 12 weeks of age, and that the overall length of the dendrites increases from 518 $\mu \mathrm{m}$ to $5471 \mu \mathrm{m}$.

\section{Postnatal increase in the number of synapses within glomeruli}

The number of synapses in the glomerular neuropil (Fig. 11A) was assessed by measuring synaptic density as a function of age. Synaptic numbers per unit area, including all types of synaptic specializations, increase throughout the first 10-12 weeks of life (Fig. 12A). The mean length of pre- and postsynaptic apposition at individual contacts, however, does not change significantly $(0.206 \pm 0.007 \mu \mathrm{m}, n=229 \pm \mathrm{SEM}$ at birth and $0.211 \pm 0.009$ $\mu \mathrm{m}, n=722$ at 12 weeks). Thus, it is unlikely that developmental changes in the complexity of terminals affect these density measurements.

The increase in synaptic number per unit area between birth and maturity is about 3-fold. Glomerular volume, however, increases markedly over this period, as does the volume of the
Table 1. The length of mitral cell dendritic processes and the number of dendritic branch points as a function of postnatal age.

\begin{tabular}{llllll} 
Age & Cell & $\begin{array}{l}\text { Measured } \\
\text { dendritic } \\
\text { lengths } \\
(\mu \mathrm{m})\end{array}$ & $\begin{array}{l}\text { Mean } \\
\text { dendritic } \\
\text { lengths } \\
(\mu \mathrm{m})\end{array}$ & $\begin{array}{l}\text { Number } \\
\text { of branch } \\
\text { points }\end{array}$ & $\begin{array}{l}\text { Mean } \\
\text { number } \\
\text { branch } \\
\text { points }\end{array}$ \\
\hline Newborn & 1 & 273 & & 21 & \\
& 2 & 195 & 518 & 17 & 37 \\
1 week & 3 & 1087 & & 72 & \\
& 1 & 1053 & & 73 & \\
3 & 2 & 550 & 992 & 44 & 67 \\
3 weeks & 3 & 1372 & & 85 & \\
& 1 & 1909 & & 109 & \\
6 & 2 & 1501 & 1658 & 72 & 93 \\
& 3 & 1564 & & 99 & \\
12 weeks & 1 & 2494 & & 131 & \\
& 2 & 2455 & 2193 & 136 & 115 \\
& 3 & 1631 & & 77 & \\
& 1 & 7081 & & 255 & \\
& 2 & 4937 & 5471 & 291 & 272 \\
& 3 & 4397 & & 271 &
\end{tabular}

Values were obtained from measurements of a series of optical sections through the apical dendrites of representative DiI-stained mitral cells imaged by confocal microscopy. The complexity and length of mitral cell dendrites increases progressively over the first 12 weeks of life.

entire bulb (see Figs. 3, 5, 6). Accordingly, the overall increase in the number of synapses in each glomerulus is far greater during maturation than indicated by these density measurements alone. An accurate assessment of the magnitude of the absolute increase in synaptic numbers is difficult to make with confidence because of assumptions that must be made in such stereological calculations. Using a relatively simple method for estimating synapse density per unit volume (Colonnier and Beaulieu, 1985), the estimated number of synapses in a typical glomerulus increases from about 7000 synapses at birth to 190,000 at 12 weeks of age. Correspondingly, the total number of glomerular synapses, estimated by multiplying the number of synapses/glomerulus by the corrected number of glomeruli (see above), increases from about 2 million at birth to 250 million at 10-12 weeks of age (Fig. 12B).

\section{Postnatal increase in the number of external plexiform synapses}

The prevalence of synapses per unit area in the external plexiform layer, which does not receive primary olfactory afferent terminals (Golgi, 1874; Ramón y Cajal, 1890; Pinching and Powell, 1971), also increases markedly in postnatal life (Fig. 13). And, as in the case of glomeruli, the overall volume of the external plexiform layer grows substantially. Consequently, the total number of synapses in the external plexiform layer, estimated as for the glomeruli, increases from about 3-4 million at birth to about a billion at 10-12 weeks of age. Although the mean length of synaptic apposition is greater than that measured for synapses in the glomerular layer, this value-like the length of glomerular synapses-does not vary systematically during maturation $(0.268 \pm 0.012 \mu \mathrm{m}$ at birth, $n=55, \pm \mathrm{SEM} ; 0.245$ \pm 0.013 at 12 weeks, $n=434$ ).

The magnitude of the postnatal increases we have measured for both glomerular and extraglomerular synapses is consistent 

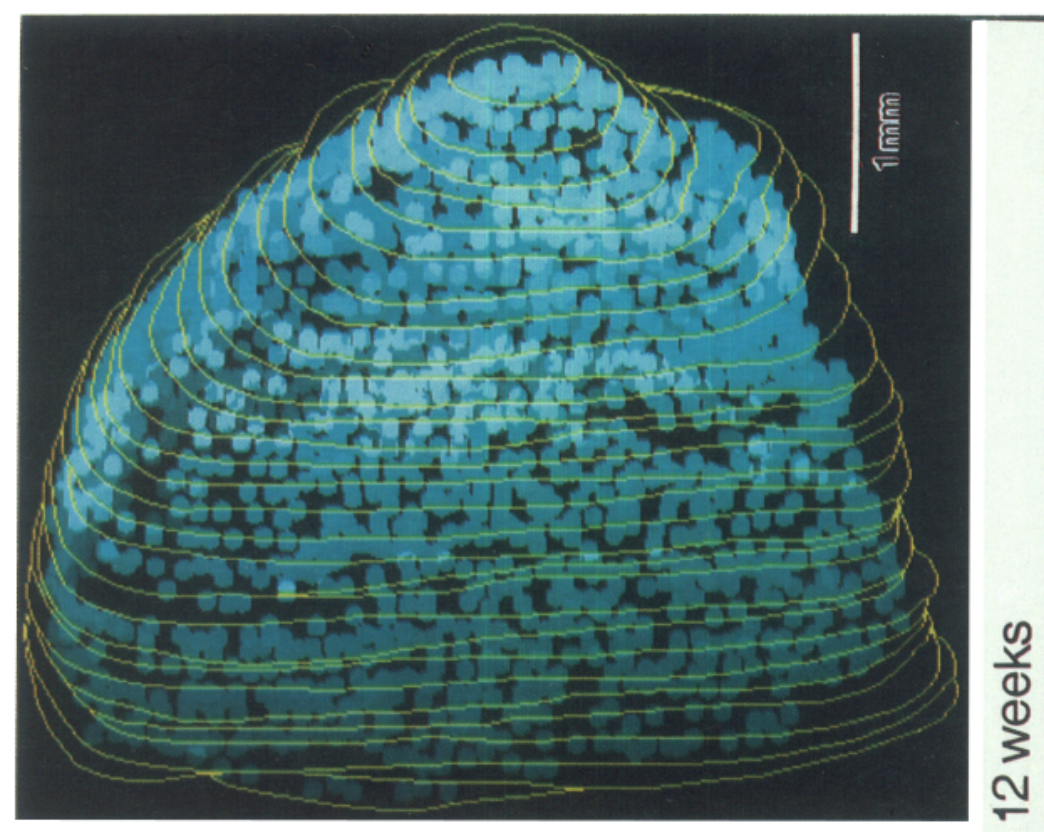

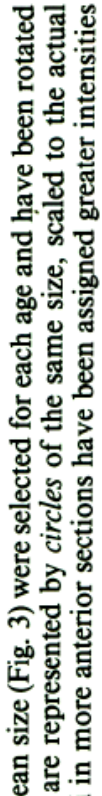

등구

․ㅡㄹ

क

政

家吉

엉

论

ㄴㅇㅇ

흥굴 중

중



远

응도

을

密
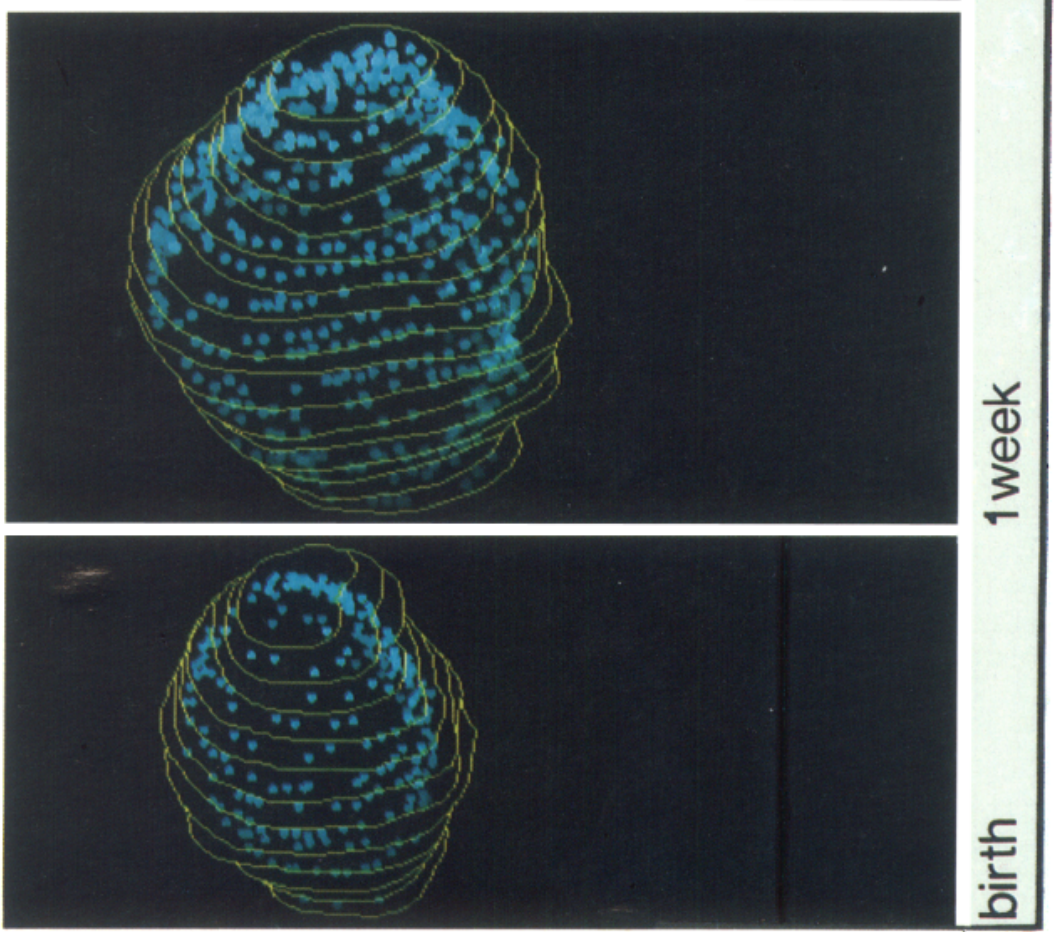

둥당

可总 ఫ

등

气。

드를

용

은

这的要

的解

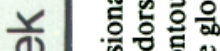

(1)

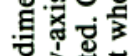

궐

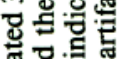

해요 品 의 政品 的

능

○은

ह ह

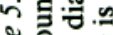

今。용

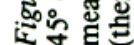




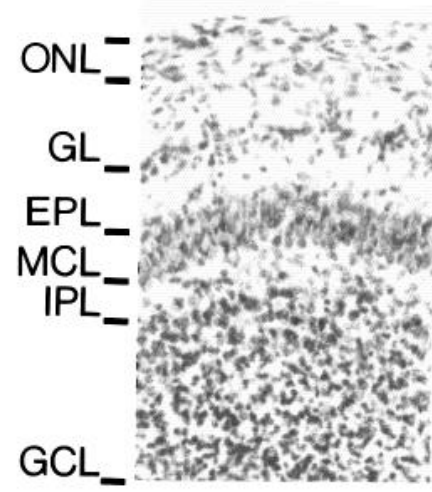

birth

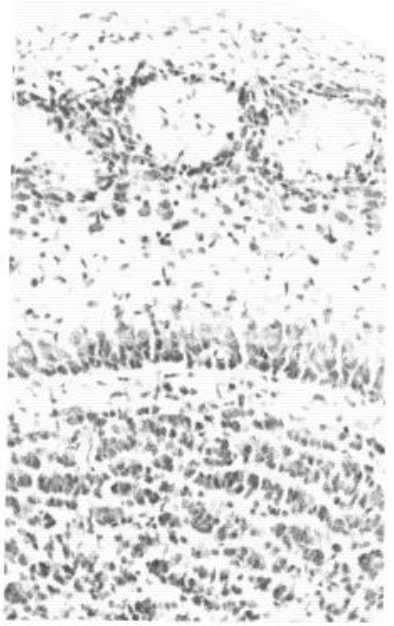

2 weeks

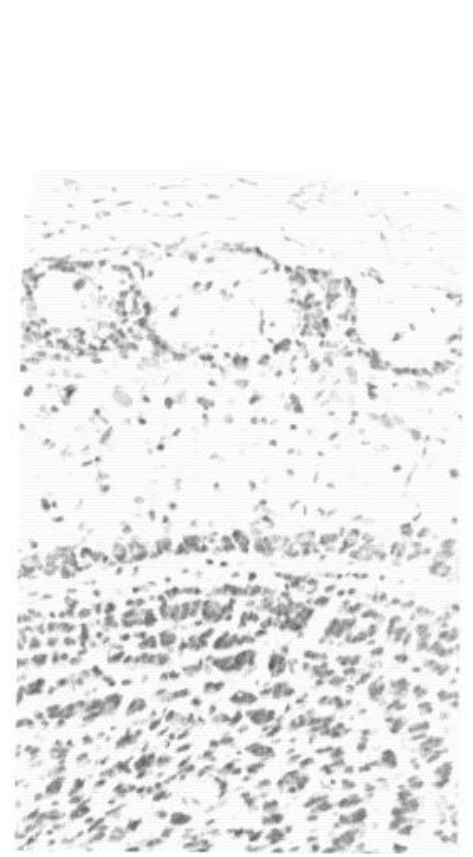

4 weeks

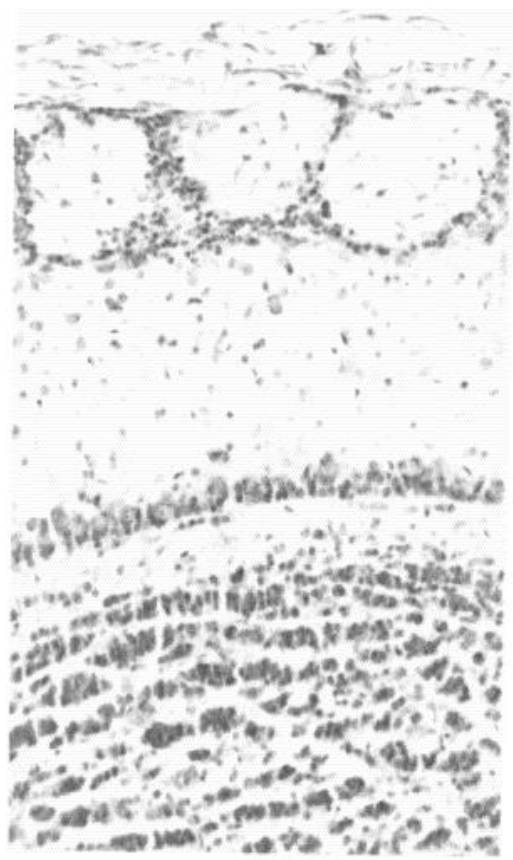

12 weeks

$50 \mathrm{~mm}$

Figure 6. Histological appearance of the olfactory bulbs in CF1 male mice at several ages from birth to maturity. All panels show the dorsalmedial portion of the right bulb in cresyl violet-stained $50 \mu$ m-thick sections. Note particularly the increasing size of the glomeruli and the progressively greater thickness of external plexiform layer. The glomeruli are discrete spheres of neuropil comprising primarily the apical dendritic tufts of mitral cells, the dendrites of tufted and other neurons, and the terminals of a large number of afferent axons. The borders of glomeruli are demarcated by a rind of darkly staining periglomerular cells (glia and small neurons). $O N L$, olfactory nerve fiber layer; $G L$, glomerular layer; $E P L$, external plexiform layer; $M C L$, mitral cell layer; $I P L$, internal plexiform layer; $G C L$, granule cell layer.

with an earlier study in which volumetric determinations from serial sections were used to estimate the number of synapses in the mouse bulb over the first several weeks of life (Hinds and Hinds, 1976).

\section{Discussion}

Our analysis of the mouse olfactory bulbs shows a gain of functional circuits and their constituent elements during the entire period of postnatal maturation. Thus, the number of complex circuits that process olfactory information (the glomeruli), the number and complexity of mitral cell branches, and the number of glomerular and extraglomerular synapses all increase throughout early life. This process is most pronounced during the first several postnatal weeks, but is apparent until 10-12 weeks of age, a time well beyond sexual maturity (which occurs at 6-7 weeks). The numbers of neural circuits and their constituent elements are apparently stable between 12 and 24 weeks of age, the latter age representing approximately $25 \%$ of the lifespan. That these numbers eventually reach a stable adult value does not rule out further change in postmature animals. For example, persistent growth and retraction of neurites occurs in several sites in the peripheral nervous system of adult mice, where identified dendrites and axon terminals can be observed directly (Purves et al., 1986, 1987; Pomeroy and Purves, 1988; Harris and Purves, 1989; see also below).

Of particular importance in this process of ongoing construction during development is the postnatal increase in glomeruli.
Observations of glomerular pattern over time in living mice show that these iterated units are added to the developing bulb without deletions from the initial population (LaMantia and Purves, 1989). Accordingly, the magnitude of addition of complex neural circuits in the postnatal brain can be accurately quantified simply by counting glomeruli in histological sections. The continuous addition of glomeruli, together with the increasing complexity of mitral cell dendrites and the increasing numbers of glomerular synapses, shows that even large, complex neural circuits can be made and elaborated throughout the entire period of postnatal maturation.

\section{Are the olfactory bulbs different from other brain regions?}

The relevance of our observations to the development of the brain in general depends on the similarity of the olfactory and other neural systems. Two differences appear to distinguish the olfactory system from the rest of the brain: the postnatal addition of receptor cells in the nasal mucosa (Graziadei and Monti-Graziadei, 1979a, b, 1980; Meisami, 1989), and the postnatal genesis of a subpopulation of granule cells in the bulbs themselves (Hinds, 1967; Mair et al., 1982; Bayer, 1983). These features, however, may be more common than is generally thought. Certainly, the postnatal generation of sensory receptors is not unique. In the rodent eye, for example, there is extensive postnatal addition of photoreceptor cells (Young, 1985; Turner and Cepko, 1987). In the peripheral nervous system, the number of cutaneous receptor cells also increases markedly in postnatal 

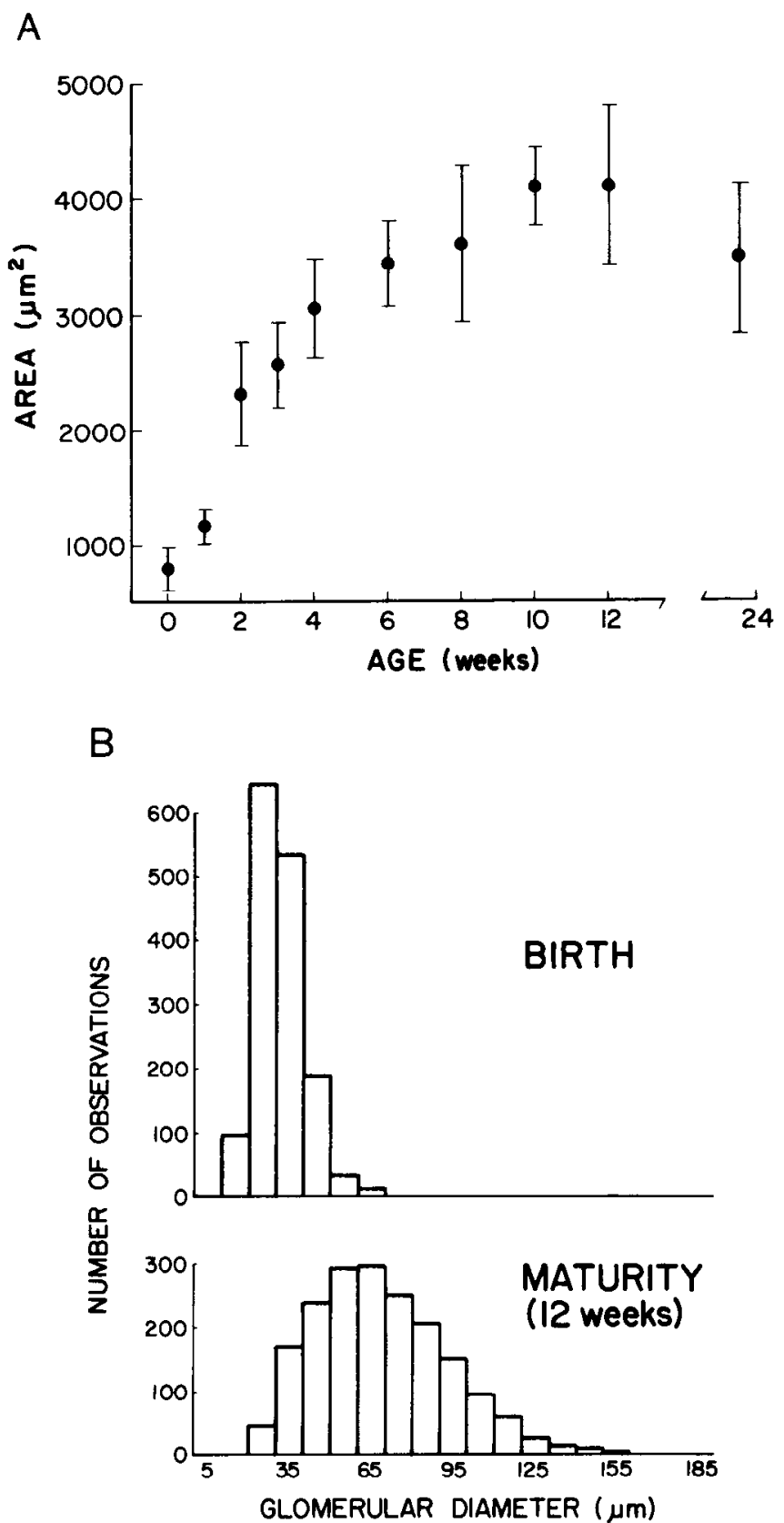

Figure 7. Changes in the size of olfactory glomeruli in CF 1 male mice from birth to 24 weeks of age. $A$, Mean cross-sectional area of glomeruli in progressively older animals. Areas were determined by measurement of about 200 glomeruli from several adjacent sections from the midregion of the olfactory bulbs of each of at least 5 different animals at the ages indicated; error bars show the standard deviation. $B$. Distribution of glomerular diameters at birth (above) and maturity (below; 12 weeks); approximately 2000 glomeruli were measured at each age in at least 5 different animals. Diameters were calculated from the observed crosssectional areas $(A)$, as described in Materials and Methods.

rodents (Nurse and Diamond, 1984; Mills et al., 1989). Similarly, postnatal neurogenesis occurs in several other regions of the developing mammalian brain, including the cortex, cerebellum, and hippocampus (Miale and Sidman, 1961; Angevine and Sidman, 1962; Altman, 1963; Altman and Das, 1965; Angevine, 1965; Altman and Bayer, 1977; Bayer et al., 1982). Postnatal neurogenesis no doubt contributes importantly to the increases in circuits and their elements that we describe here in the olfactory bulb. It is quite clear, however, that stable populations of neurons such as mitral cells, which are all generated before birth (Hinds, 1967), also make a major contribution to these postnatal changes. The dendrites of mitral cells, for example, increase in complexity by an order of magnitude between birth and full maturity. Indeed, ongoing elaboration of dendrites and axon terminals is well documented in several other parts of the postnatal mammalian brain (reviewed in Purves, 1988). Finally, other vertebrates-some fish and birds-provide evidence of some neural construction throughout life (Nottebohm, 1981; Easter, 1983; Konishi, 1989). These arguments notwithstanding, the degree and duration of postnatal circuit construction in other parts of the mammalian brain must be evaluated directly by the kind of analysis we report here for the olfactory bulb.

\section{Are glomeruli comparable to other analytic units in the mammalian brain?}

Many regions of the mammalian brain are characterized by iterated ensembles of nerve cells and their connections that, like olfactory glomeruli, can be distinguished both anatomically and physiologically. Some examples are columns in the visual cortex (reviewed in Hubel, 1988), columns and barrels in the somatosensory cortex (Mountcastle, 1957, 1978; Powell and Mountcastle, 1959; Woolsey and Van der Loos, 1970; Jones et al., 1975; Rice and Van der Loos, 1977), the "blobs" in the visual cortex (Horton, 1984; Tootell et al., 1985; Hockfield and Tootell, 1987; Hubel and Livingstone, 1987), "barreloids" in the thalamus (Van der Loos, 1976), and striasomes and cell islands in the caudate nucleus and putamen (Graybiel and Ragsdale, 1978, Graybicl ct al., 1979; Goldman-Rakic, 1982; Graybiel and Hickey, 1982; Gerfen, 1989). In each case, subsets of afferent fibers form well-circumscribed domains of neuropil, with the dendritic processes of neurons in the target region often conforming to this pattern. In layer IV of the rodent barrel cortex, for example, the structure of individual barrels closely resembles the structure of glomeruli. Each barrel is characterized by a zone of neuropil surrounded by a rind of closely packed neurons and glial cells, with the dendrites of the target neurons largely confined to the central neuropil (Woolsey and van der Loos, 1970; Simons and Woolsey, 1984). Ocular dominance columns in the primary visual cortex of some mammals also share these properties. Each column (or stripe) is defined by discrete domains of afferents (LeVay et al., 1978), with the dendrites of layer IV neurons tending to obey the column boundaries (Katz et al., 1989).

Given these similarities, an important qucstion is whcther most or all iterated ensembles in the brain develop in the same manner and, in the context of the present study, whether such units are usually generated over a prolonged postnatal period. In the mouse olfactory bulb, the number of glomeruli gradually increases to more than 4 times the neonatal number by 12 weeks of age. Clearly, postnatal addition does not occur among all iterated ensembles. For instance, the number of barrels in the rodent somatosensory cortex is stable from the time they can first be detected in animals 4-5 d old (Rice and Van der Loos, 1977; Killackey and Belford, 1979). Mice do not have ocular dominance columns (Drager, 1978), and whether more columns are present in mature cats and monkeys than newborns is not known. Similarly, the numerical change, if any, among other iterated units in the visual cortex has not been examined. The final number of iterated ensembles may be determined quite 


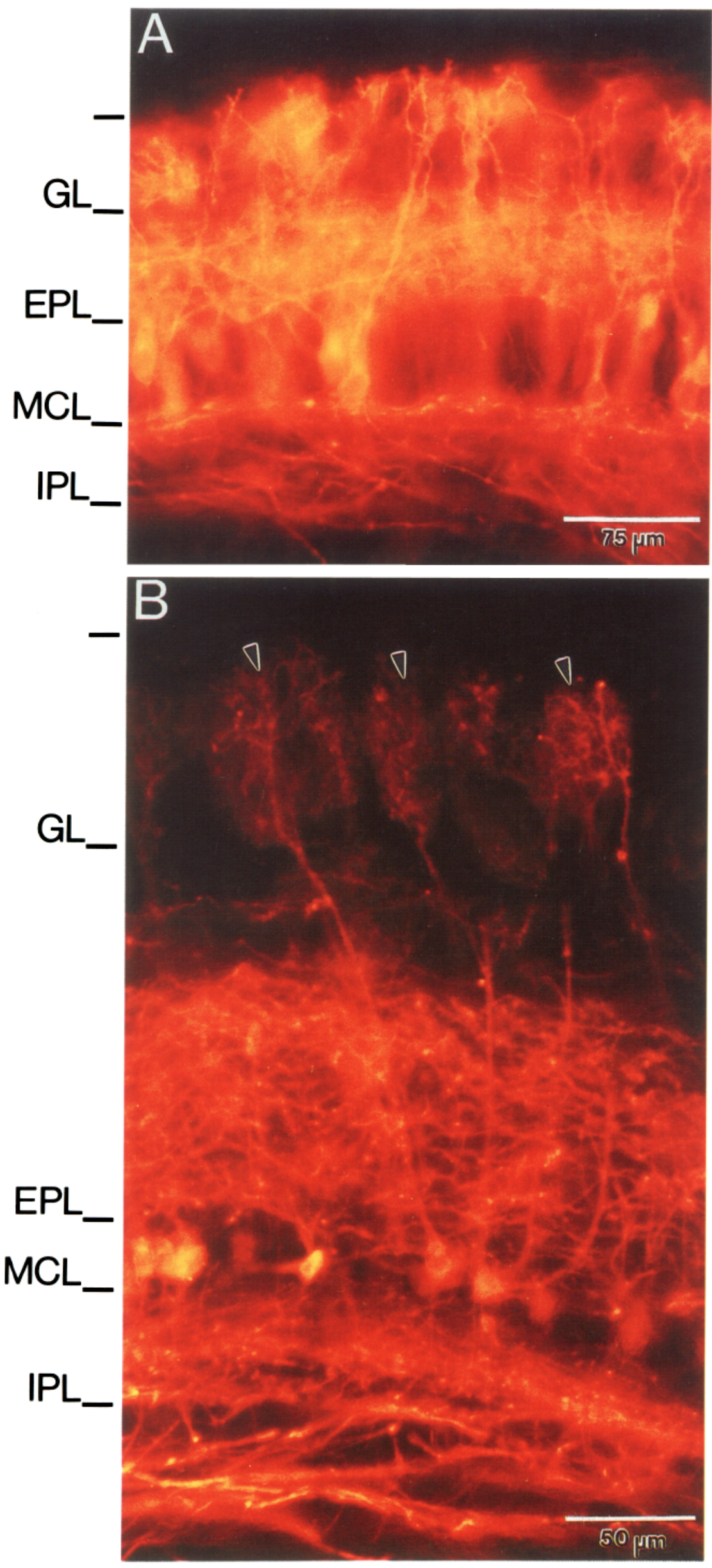

Figure 8. Photomicrographs of mitral cells in $75 \mu \mathrm{m}$-thick sections of the olfactory bulb visualized by retrograde DiI labeling from the lateral olfactory tract. $A$, Appearance of labeled mitral cells and their branches at birth. $B$, Mitral cells and their processes in adult mice (12 weeks). The mitral cells are much larger, with more complex apical dendritic tufts (arrowheads; see also Fig. 10). The lateral dendrites of mitral cells have also grown to form a thick, welldefined external plexiform layer. $G L$, glomerular layer; $E P L$, external plexiform layer; $M C L$, mitral cell layer; $I P L$, internal plexiform layer. 


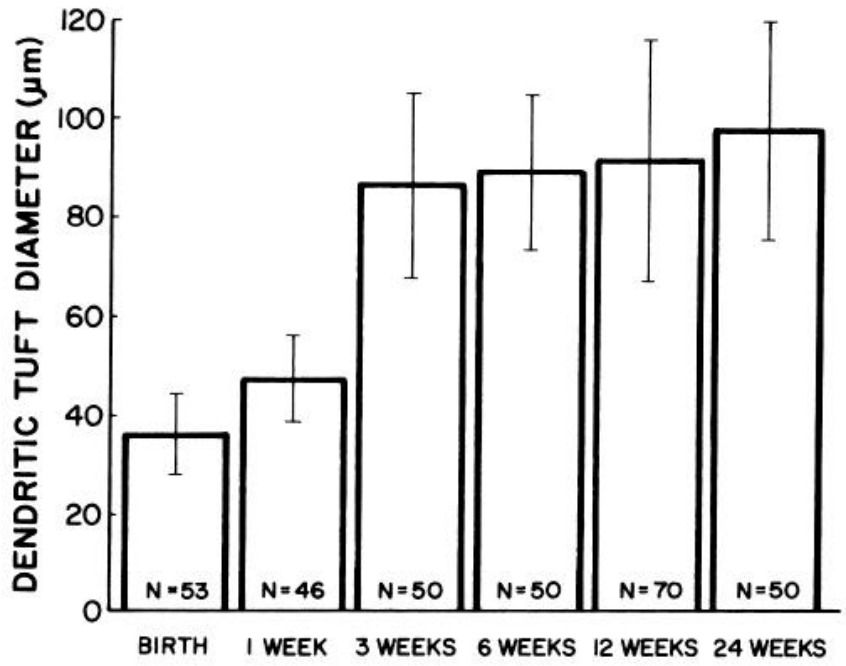

Figure 9. Mean diameters of mitral cell apical dendritic tufts, measured on a digitizing tablet from camera lucida tracings. Diameters were calculated by measuring the area enclosed by a perimeter drawn around the dendritic branches within glomeruli and then determining the diameter of an equivalent circle. The overall size of the area of the dendritic branches within glomeruli increases markedly during the first 12 weeks of life. Note that the mean glomerular diameters measured here are somewhat larger than those determined in glutaraldehyde-fixed bulbs (see Fig. 7), presumably because of the inclusion of glomerular fragments in measurements from the thinner cresyl violet-stained sections (see Materials and Methods). early in those regions of the brain where development is constrained by early maturation of the related periphery. The prolonged postnatal construction of entirely new circuits-in the style of postnatal glomerular addition-may occur, however, in brain regions in which: (1) the related periphery grows substantially during maturation; (2) there is no isomorphic relation between the iterated neuronal circuits and the peripheral structure they serve; or (3) the relation to the periphery is remote.

\section{The relation of ongoing neural construction to regression and selection during development}

The prominence of regressive events in neural development is well established, particularly in those parts of the nervous system directly related to the periphery (reviewed in Purves and Lichtman, 1985). In general, such regressive phenomena can be divided into 3 categories: cell death, the elimination of axonal projections, and synapse elimination. Although none of these events has been studied explicitly in the olfactory system, there may well be regressive changes in the developing olfactory bulbs. Be this as it may, our findings show that the dominant quantitative theme in this part of the nervous system is the progressive addition of synapses, neuronal branches, and functional circuits. We find no indication of a net loss of any of these elements from an initial surfeit.

This evidence differs from a number of studies which have concluded that there is a net elimination of synapses in the postnatal cerebral cortex, and that this process has important functional consequences (Huttenlocher, 1979; Huttenlocher et al., 1982; Garey and de Courten, 1983; Rakic et al., 1986; Huttenlocher and de Courten, 1987; Bourgeois et al., 1989). In each

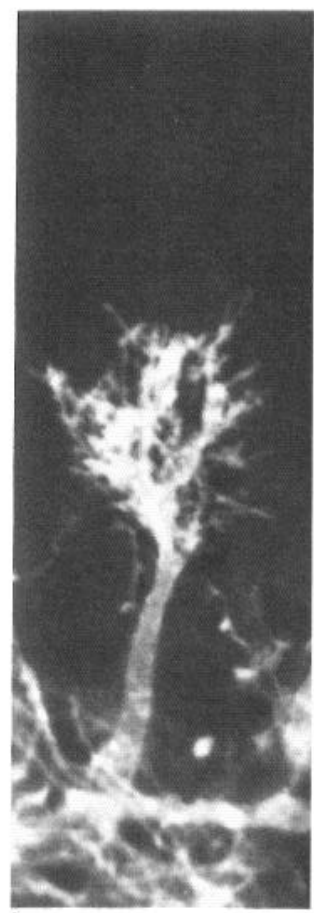

birth

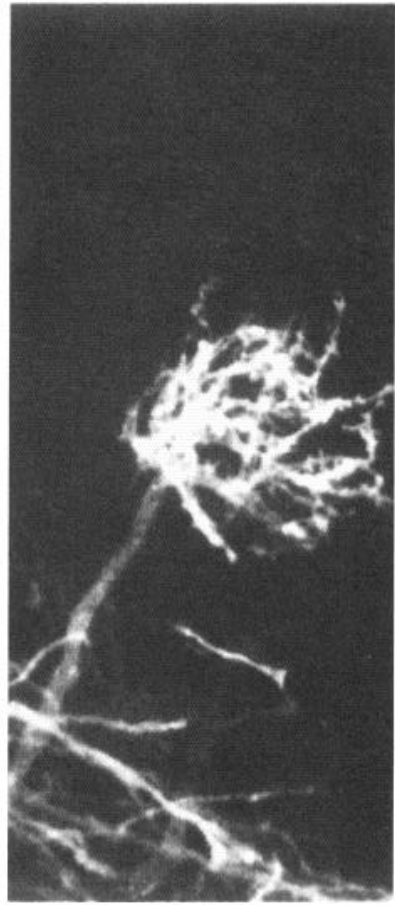

1 week

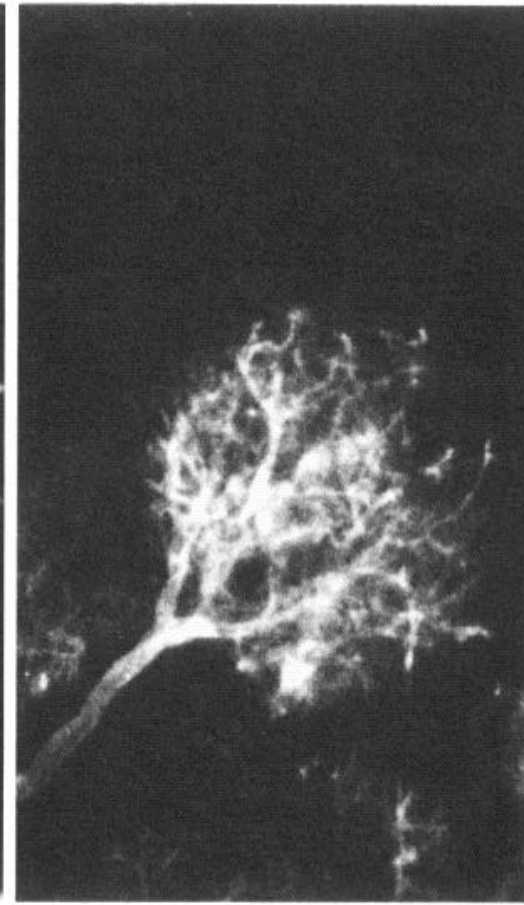

6 weeks

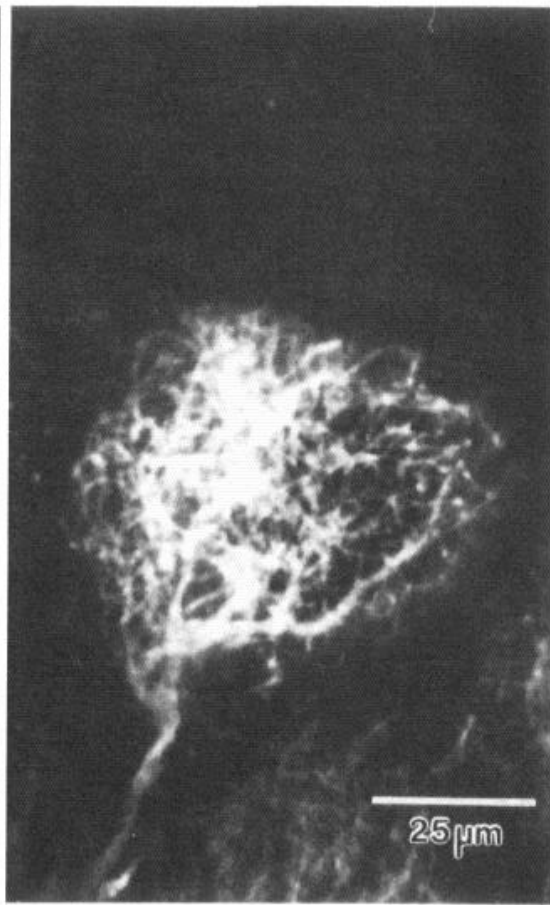

12 weeks

Figure 10. Reconstructions of a series of confocal images through representative mitral cell apical dendritic tufts after DiI labeling at different ages. Images include 30-60 focal planes taken through the entire depth of the tuft (see text). With increasing age, the tufts become progressively larger and the branching within them more extensive (see Table 1 for quantitation). 


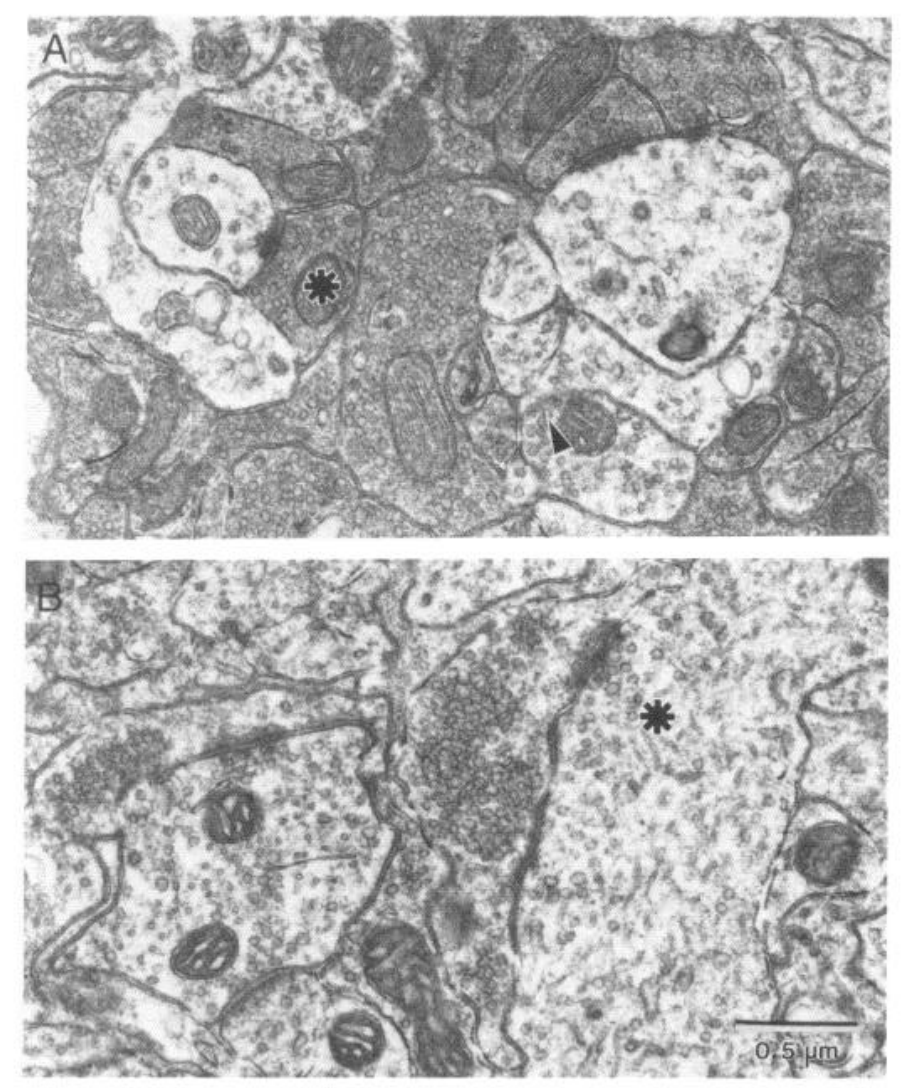

Figure 11. Representative electron micrographs of olfactory bulb synapses in mature CF1 male mice. $A$, Synapses in the glomerular neuropil. The predominant synaptic type (asterisk) arises from primary afferent terminals and is characterized by dark, vesicle-filled profiles opposed to lighter postsynaptic dendrites of mitral cells (Pinching and Powell, 1971). Occasional lighter presynaptic profiles (arrowhead) probably represent axon terminals of periglomerular and granule cells. $B$, Neuropil of the external plexiform layer. Reciprocal synapses (asterisk), probably between granule cell dendrites and mitral cell dendrites, form the predominant synaptic type. To be counted as a synapse (see Fig. 12), specializations had to be characterized by pre- and postsynaptic thickenings and synaptic vesicles.

of these studies, the conclusions have been based on interpretations of measurements of synaptic numbers per unit area of electron microscopic sections. A possible explanation of the discrepancy between these studies and the present results is the difficulty correcting for changes in the overall volume of the cortex, particularly in primates. Alternatively, the substantial postnatal growth of the cerebral cortex might not be based on the same progressive construction of neural circuitry evident in the olfactory bulb. Certainly, this issue should be explored.

The prevalence of regressive phenomena in neural development has been used to support a number of currently popular theories of brain function based on the selection of a subset of circuits from a larger initial repertoire of neural connections (Changeux et al., 1973; Young, 1973, 1979; Changeux and Danchin, 1976; Edelman, 1978, 1987; Changeux, 1985). In their simplest form, selectionist theories argue that there is an excess of neuronal interconnections early in life; those connections that prove useful during development are "stabilized," whereas the rest are lost or suppressed. Our results in the olfactory system militate against this version of the selectionist view. In at least this part of the developing mouse brain, the numbers of func-
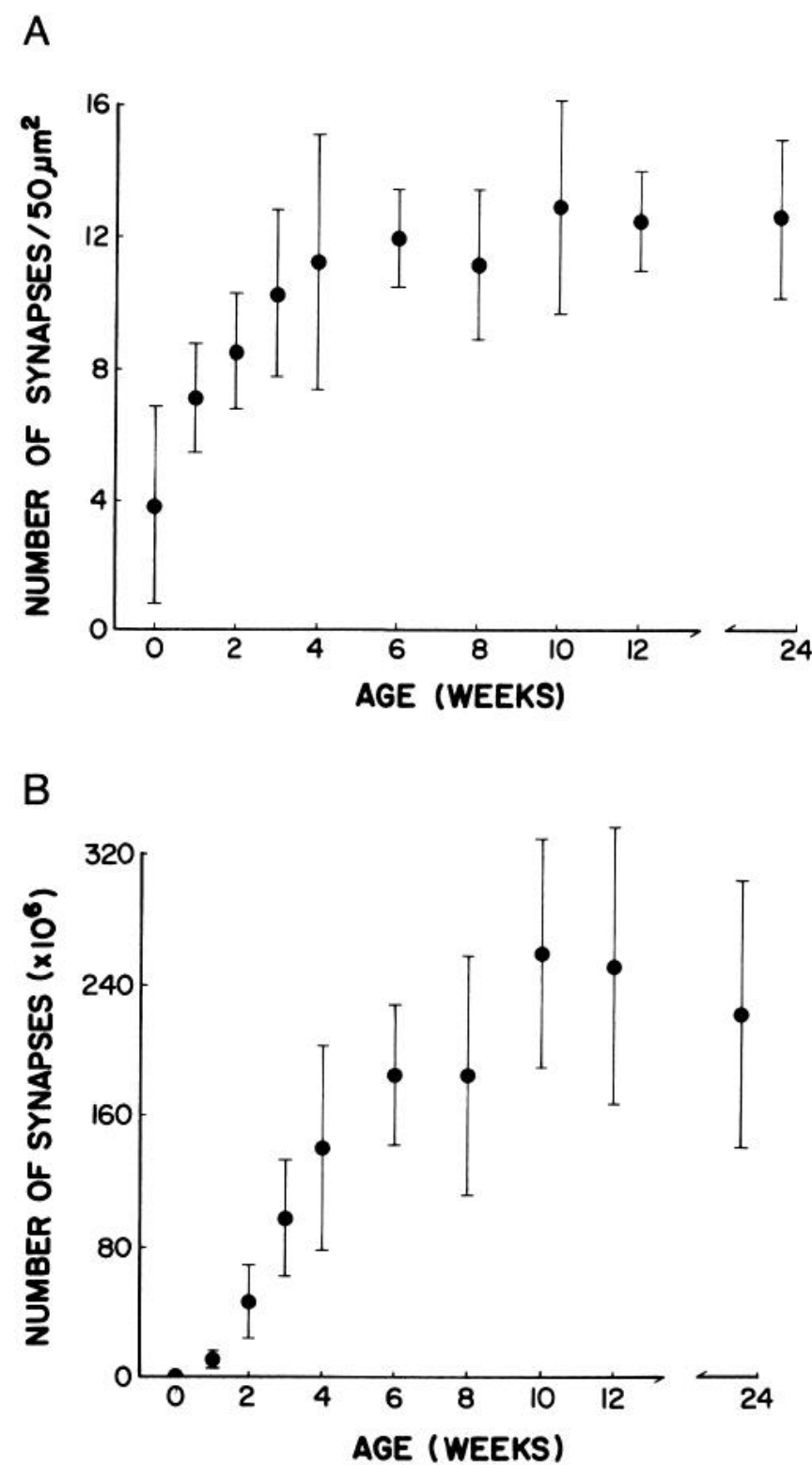

Figure 12. Estimated number of synapses in olfactory glomeruli of CF1 male mice from birth to 24 weeks of age. $A$, Mean number of synaptic contacts per unit area $\left(50 \mu \mathrm{m}^{2}\right)$ as a function of age; each point represents measurements (see Materials and Methods) from at least 10 bulbs at each age. Error bars show standard deviation. $B$, Estimated total number of glomerular synapses in progressively older animals, calculated from the synaptic number per unit volume (see text), the corrected number of glomeruli at each age, and glomerular size (Fig. 7).

tional circuits and their constituent elements increase throughout the full period of maturation. The progressive construction of neural circuits in the olfactory system-and perhaps elsewhere in the brain-is not easily reconciled with any scheme predicated on the existence of a larger repertoire of neuronal interconnections in early life.

\section{Neural construction as a possible explanation for several aspects of neural development}

The prolonged postnatal construction of this part of the nervous system may be pertinent to several poorly understood aspects of neural development: the prevalence of critical periods, the 


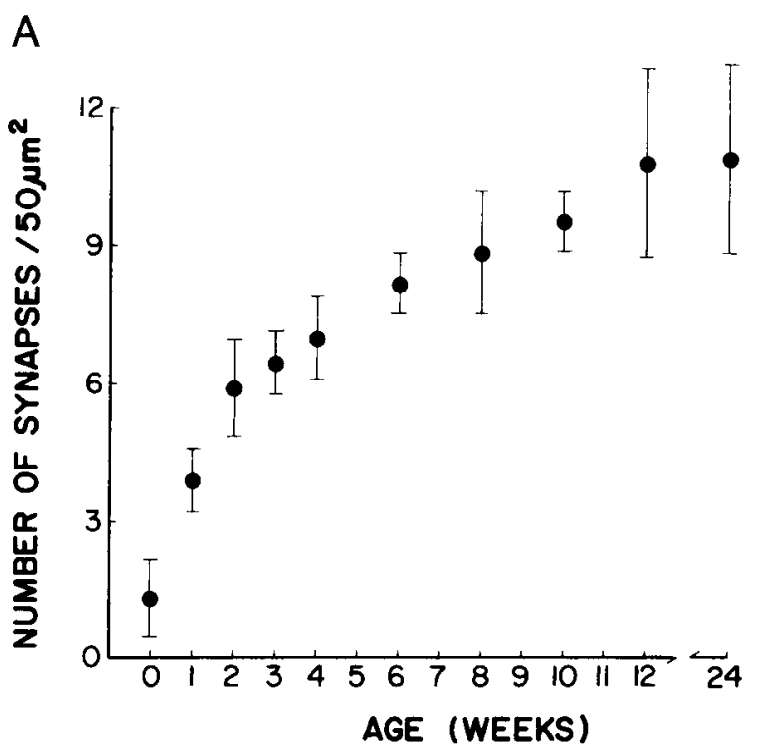

B

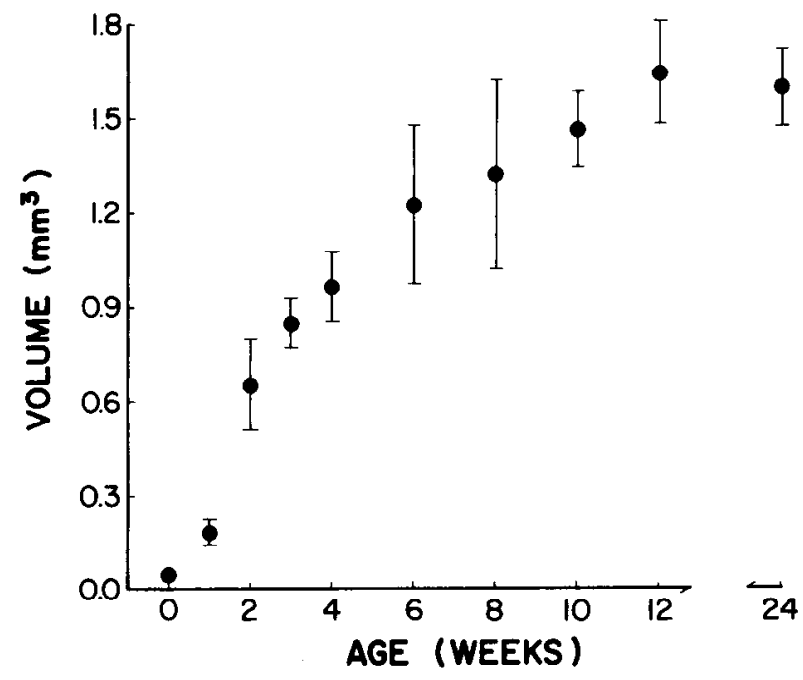

C

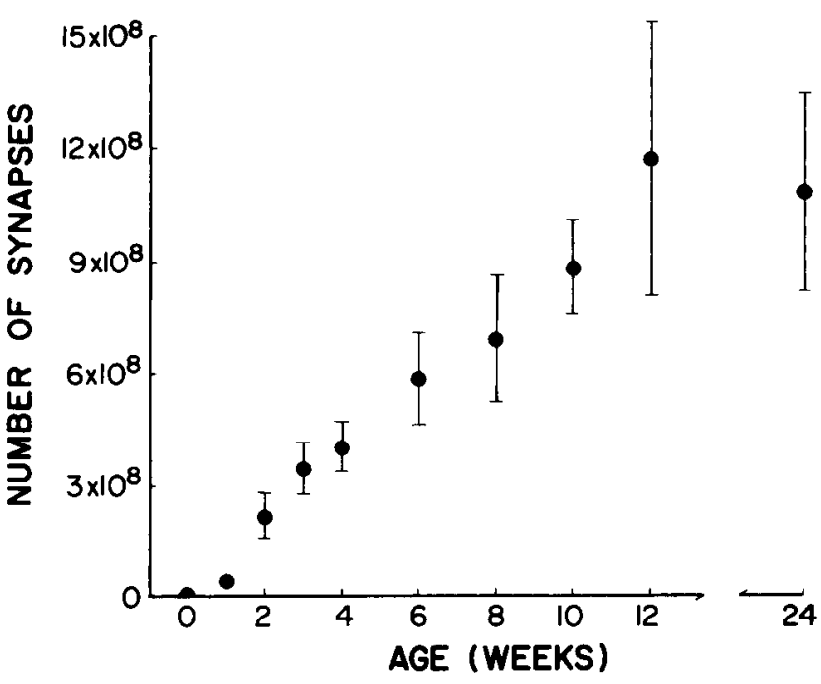

Figure 13. Estimated number of synapses in the external plexiform layer of CF1 male mice from birth to 24 weeks of age. $A$, Mean number age-dependent response of the nervous system to injury, and the ability of the juvenile nervous system to store permanently very large amounts of new information.

Critical periods (or sensitive phases; see Immelmann and Suomi, 1981) are limited intervals in neural developmentassessed by physiological, anatomical, or behavioral criteriaduring which the nervous system can change in response to altered circumstances. The end of a critical period is defined as the time when the same conditions are no longer effective in eliciting the change observed earlier. Perhaps the most thoroughly studied example of this phenomenon is the period in early life when visual experience can alter the structure and function of the visual cortex (Hubel et al., 1977; Hubel, 1988). One interpretation of this work has been that critical periods are explained by the regression of initial connections that fail to receive functional validation during early life. Another interpretation, suggested by the present results, is that critical periods are explained by the elaboration of new circuits. In this view, the persistence of constructive, rather than regressive, events determines the duration of the critical period for any given system. There is, of course, no reason why critical periods cannot involve both regressive and constructive processes. Nevertheless, the role of postnatal circuit construction has not, to our knowledge, been much considered in thinking about how critical periods might be explained.

Another phenomenon, quite possibly related to critical periods, is the age-dependent response of the central nervous system to injury. Both clinical observation (Berger et al., 1985; Alberico et al., 1987; Luerssen et al., 1988) and animal experiments (Kennard, 1942; Bregman and Goldberger, 1983) indicate that the nervous systems of younger animals cope more successfully with neural injury than the nervous systems of older animals. Perhaps the most striking clinical example of this phenomenon is the ability of infants and young children to compensate for resection of a large and important region of the brain, such as the removal of an entire hemisphere (McFie, 1961). This age-dependent response to injury might also be explained by the persistent ability to construct complex neural circuits in the brain during the early years of human life.

Finally, ongoing construction of neural circuits evident in the mouse olfactory system may be pertinent to the way in which the nervous system normally encodes information. There is, at present, a consensus that experience is encoded by altering the functional efficacy of synapses in existing neural circuits (see, for example, Kandel and Schwartz, 1982). A different view, suggested by the present results, is that the encoding of much information in the developing mammalian brain depends on the construction of additional neural circuits, including even large, complex ensembles such as glomeruli. of synaptic contacts per unit area $\left(50 \mu \mathrm{m}^{2}\right)$ as a function of age; each point represents measurements from at least 5 bulbs at each age. Error bars show standard deviation. The increased prevalence of synapses with age was approximately the same at all 3 vertical positions sampled within the external plexiform layer. $B$, Volume of the external plexiform layer at different ages, determined from tracings of serial sections through each bulb examined (see Materials and Methods). $C$, Estimated number of synapses in the external plexiform layer of progressively older animals, calculated from the synaptic number per unit volume and the measured laminar volume $(B)$. 


\section{Conclusion}

The basis for the overall growth of the mammalian brain in postnatal life, and the relevance of such growth to several neurobiological and clinical issues, has not been much examined. In the present work we have demonstrated that, in a relatively simple part of the brain particularly amenable to quantitative analysis, postnatal growth refiects a prolonged and progressive increase in the numbers of synapses, neuronal branches, and complex circuits formed by these elements. Whether this developmental strategy applies to the rest of the brain is not yet known; the postnatal growth of the mouse olfactory bulb appears, however, to be roughly commensurate with that of the brain as a whole.

Based on our examination of the olfactory bulb, we suggest that the ongoing postnatal construction of neural circuitry and its gradual cessation may provide a cellular basis for several developmental phenomena whose explanation is now obscure. These include the occurrence of critical periods, the different response of the nervous system to injury at various ages, and the means by which much information presented to young animals is normally encoded in the nervous system. Such phenomena may be better explained by the formation of new circuits and their constituent elements than by the selection or stabilization of existing ones. In any event, the construction of neural circuitry is, from the quantitative perspective, the dominant themc in the postnatal development of this part of the mouse CNS. Whether this theme is characteristic of the rest of the mammalian brain should be investigated.

\section{References}

Abercrombie M (1946) Estimation of nuclear population from microtome sections. Anat Rec 94:239-247.

Alberico AM, Ward JD, Choi SC, Marmarou A, Young HF (1987) Outcome after severe head injury. Relationship to mass lesions, diffuse injury, and ICP course in pediatric and adult patients. J Neurosurg 67:648-656.

Altman J (1963) Autoradiographic investigation of cell proliferation in the brains of rats and cats. Anat Rec 145:573-591.

Altman J, Bayer SA (1977) Timc of origin and distribution of a new cell type in rat cerebellar cortex. Exp Brain Res 29:265-274.

Altman J, Das GD (1965) Autoradiographic and histological evidence of postnatal hippocampal neurogenesis in rats. J Comp Neurol 124: 319-336.

Angevine JB (1965) Time of neuron origin in the hippocampal region: an autoradiographic study in the mouse. Exp Neurol Suppl 2:1-70.

Angevine JB, Sidman RL (1962) Autoradiographic study of histogenesis in the cerebral cortex of the mouse. Anat Rec 142:210.

Bayer SA (1983) ${ }^{3} \mathrm{H}$-Thymidine-radiographic studies of neurogenesis in the rat olfactory bulb. Exp Brain Res 50:320-340.

Bayer SA, Yackel JW, Puri PS (1982) Neurons in the rat dentate gyrus granular layer substantially increase during juvenile and adult life. Science 216:890-892.

Berger MS, Pitts LH, Lovcly M, Edwards MSB, Bartkowski HM (1985) Outcome from severe head injury in children and adolescents. J Neurosurg 62:194-199.

Bourgeois J-P, Jastreboff PJ, Rakic P (1989) Synaptogenesis in visual cortex of normal and preterm monkeys: evidence for intrinsic regulation of synaptic overproduction. Proc Natl Acad Sci USA 86:42974301.

Bregman BS, Goldberger ME (1983) Infant lesion effect. III. Anatomical correlates of sparing and recovery of function after spinal cord damage in newborn and adult cats. Dev Brain Res 9:137-154.

Changeux J-P (1985) Neuronal man: the biology of mind. (Garey L, trans.). New York: Pantheon.

Changeux J-P, Danchin A (1976) Selective stabilisation of developing synapses as a mechanism for the specification of neuronal networks. Nature 264:705-712.

Changeux J-P, Courrège $P$, Danchin A (1973) A theory of the epi- genesis of neuronal networks by selective stabilization of synapses. Proc Natl Acad Sci USA 70:2974-2978.

Colonnier M, Beaulieu C (1985) An empirical assessment of stereological formulae applied to the counting of synaptic disks in the cerebral cortex. J Comp Neurol 231:175-179.

Copoletta JM, Wolbach SB (1933) Body length and organ weight of infants and children. Am J Pathol 9:55-70.

Cowan WM, Fawcett JW, O'Leary DDM, Stanfield BB (1984) Regressive events in neurogenesis. Science 225:1258-1265.

Dekaban AS, Sadowsky D (1978) Changes in brain weights during the span of human life: relation of brain weights to body heights and body weights. Ann Neurol 4:345-356.

Drager U (1978) Observations of monocular deprivation in mice. $\mathbf{J}$ Neurophysiol 41:28-42.

Easter SS (1983) Postnatal neurogenesis and changing connections. Trends Neurosci 6:53-56.

Edelman GM (1978) Group selection and phasic reentrant signalling: a theory of higher brain function. In: The mindful brain: cortical organization and the group-selective theory of higher brain function (Edelman, GM, Mountcastle VB, eds), pp 55-100. Cambridge MA: MIT Press.

Edelman GM (1987) Neural Darwinsim: the theory of neuronal group selection. New York: Basic.

Garey LJ, de Courten C (1983) Structural development of the lateral geniculate nucleus and visual cortex in monkey and man. Behav Brain Res 10:3-13.

Gerfen CR (1989) The neostriatal mosaic: striatal patch-matrix organization is related to cortical lamination. Science 246:385-388.

Goldman-Rakic PS (1982) Cytoarchitectonic heterogeneity of the primate neostriatum: subdivision into island and matrix cellular compartments. J Comp Neurol 205:398-413.

Golgi C (1874) Sulla fina struttura dei bulbi olfattorii. Riv Sper Freniat Med leg Alien Ment 1:405-425.

Graybiel AM, Hickey TL (1982) Chemospecificity of ontogenetic units in the striatum: demonstration by combining $\left[{ }^{3} \mathrm{H}\right]$ thymidine neuronography and histochemical staining. Proc Natl Acad Sci USA 79:198202.

Graybiel AM, Ragsdale CW (1978) Histochemically distinct compartments in the striatum of human being, monkey and cat demonstrated by the acetylthiocholinesterase staining method. Proc Natl Acad Sci USA 75:5723-5726.

Graybiel AM, Ragsdale CW Jr, Edley SM (1979) Compartments in the striatum of the cat observed by retrograde cell labeling. Exp Brain Res 34:189-195.

Graziadei PPC, Monti-Graziadei GA (1979a) Neurogenesis and neuron regeneration in the olfactory system of mammals. I. Morphological aspects of differentiation and structural organization of the olfactory sensory neurons. J Neurocytol 8:1-18.

Graziadei PPC, Monti-Graziadei GA (1979b) Neurogenesis and neuron regeneration in the olfactory system of mammals. II. Degeneration and reconstitution of the olfactory sensory neurons after axotomy. $J$ Neurocytol 8:197-213.

Graziadei PPC, Monti-Graziadei GA (1980) Neurogenesis and neuron regeneration in the olfactory system of mammals. III. Deafferentation and reinnervation of the olfactory bulb following section of the fila olfactoria in rat. J Neurocytol 9:145-162.

Gunderson HJG (1977) Notes on the elimination of the numerical density of arbitrary profiles: the edge effect. J Microsp 3:219-223.

Harris LW, Purves D (1989) Rapid remodeling of sensory endings in the corneas of living mice. J Neurosci 9:2210-2214.

Hinds JW (1967) Autoradiographic study of histogenesis in the mouse olfactory bulb. I. Time of origin of neurons and neuroglia. J Comp Neurol 134:287-304.

Hinds JW, Hinds PL (1976) Synapse formation in the mouse olfactory bulb: quantitative studies. J Comp Neurol 169:15-40.

Hockfield S, Tootell RBH (1987) Organization of human visual cortex demonstrated with monoclonal antibody Cat-301. Soc Neurosci Abstr $13: 3$.

Horton JC (1984) Cytochrome oxidase patches: a new cytoarchitectonic feature of monkey visual cortex. Phil Trans R Soc Lond B 304: 199-253.

Hubel DH (1988) Eye, brain, and vision. New York: Scientific American Library.

Hubel DH, Livingstone MS (1987) Segregation of form, color, and stereopsis in primate area 18 . J Neurosci 7:3378-3415. 
Hubel DH, Wiesel TN, LeVay S (1977) Plasticity of ocular dominance columns in the monkey striate cortex. Phil Trans R Suc Lond B 278: $377-409$.

Huttenlocher PR (1979) Synaptic density in human frontal cortex. Developmental changes and effects of aging. Brain Res 163:195-205.

Huttenlocher PR, de Courten C (1987) The development of synapses in striate cortex of man. Hum Neurobiol 6:1-9.

Huttenlocher PR, de Courten C, Garey LJ, Van der Loos H (1982) Synaptogenesis in the human visual cortex-evidence for synapse elimination during normal development. Neurosci Lett 33:247-252.

Immelmann K, Suomi SJ (1981) Sensitive phases in development. In: Behavioral development: the Bielefeld interdisciplinary project (Immelmann K, cd), pp 395-431. New York: Cambridge University Press.

Jones EG, Burton H, Porter R (1975) Commissural and corticocortical "columns" in the somatic sensory cortex of primates. Science 100 572-574.

Kandel ER, Schwartz JH (1982) Molecular biology of learning: modulation of transmitter release. Science 21 8:433-443.

Katz L, Gilbert CD, Wiesel TN (1989) Local circuits and ocular dominance columns in monkey striate cortex. J Neurosci 9:1389-1399.

Kennard MA (1942) Cortical reorganization of motor function. Studies on series of monkeys of various ages from infancy to maturity. AMA Arch Neurol Psychiatry 48:227-240.

Killackey HP, Belford GR (1979) The formation of afferent patterns in the somatosensory cortex of the neonatal rat. J Comp Neurol 183 : 285-304.

Konishi M (1989) Birdsong for neurobiologists. Neuron 3:541-549.

LaMantia A-S, Purves D (1989) Development of glomerular pattern visualized in the olfactory bulbs of living mice. Nature 341:646-649.

LeVay S, Stryker MP, Shatz CJ (1978) Ocular dominance columns and their development in layer IV of the cat's visual cortex: a quantitative study. J Comp Neurol 179:223-244.

Luerssen TG, Klauber MR, Marshall LF (1988) Outcome from head injury related to patient's age. A longitudinal prospective study of adult and pediatric head injury. J Neurosurg 68:409-416.

Mair RG, Gellman RL, Gesteland RC (1982) Postnatal proliferation and maturation of olfactory bulb neurons in the rat. Neuroscience 7 : 3105-3116.

McFie J (1961) The effects of hemispherectomy on intellectual functioning in cases of infantile hemiplegia. J Neurol Neurosurg Psychiatry $24: 240-249$.

Meisami E (1979) The developing rat olfactory bulb: prospects of a new model system in developmental neurobiology. Int Brain Res 5: 183-206.

Meisami E (1989) A proposed relationship between increases in the number of olfactory receptor neurons, convergence ratio and sensitivity in the developing rat. Dev Brain Res 46:9-19.

Meisami E, Safari L (1981) A quantitative study of the effects of early unilateral olfactory deprivation on the number and distribution of mitral and tufted cells and of glomeruli in the rat olfactory bulb. Brain Res 221:81-107.

Meisami E, Shafa F (1977) Postnatal structural development of the rat olfactory bulb and its functional significance. In: Proceedings of the sixth international symposium on olfaction and taste (LeMagnen J, MacLeod P, eds), p 198. Washington DC: Information Retrieval.

Miale IL, Sidman RL (1961) An autoradiographic analysis of histogenesis in the mouse cerebellum. Exp Neurol 4:277-296.

Mills LR, Nurse CA, Diamond J (1989) The neural dependency of Merkel cell development in the rat: the touch domes and foot pads contrasted. Dev Biol 136:61-74.

Mountcastle VB (1957) Modality and topographic properties of single neurons of cat's somatic sensory cortex. J Neurophysiol 20:408-434.

Mountcastle VB (1978) An organizing principle for cerebral function: the unit module and the distributed system. In: The mindful brain: cortical organization and the group-selective theory of higher brain function (Edelman GM, Mountcastle VB, eds), pp 7-50. Cambridge, MA: MIT Press.

Nottebohm F (1981) A brain for all seasons: cyclical anatomical changes in song control nuclei of the canary brain. Science 214:1368-1370.
Nurse CA, Diamond J (1984) A fluorescent microscopic study of the development of rat touch domes and their Merkel cells. Neuroscience 11:509-520.

Pakkenberg H, Voigt J (1964) Brain weight of the Danes. Acta Anat 56:297-307.

Pinching AJ, Powell TPS (1971) The neuropil of the glomeruli of the olfactory bulb. J Cell Sci 9:347-377.

Pomeroy SL, Purves D (1988) Neuron/glia relationships observed over intervals of several months in living mice. J Cell Biol 107:11671175.

Pomeroy SL, LaMantia A-S, Purves D (1989) Evidence that postnatal development of the mouse olfactory bulb proceeds by gradual addition of neural elements. Soc Neurosci Abstr 15:806.

Powell TPS, Mountcastle VB (1959) Some aspects of the functional organization of the cortex of the postcentral gyrus of the monkey: a correlation of findings obtained in a single unit analysis with cytoarchitecture. Bull Johns Hopkins Hosp 105:133-162.

Purves D (1988) Body and brain: a trophic theory of neural connections. Cambridge, MA: Harvard U. P.

Purves D, Lichtman JW (1980) Elimination of synapses in the developing nervous system. Science 210:153-157.

Purves D, Lichtman JW (1985) Principles of neural development. Sunderland, MA: Sinauer.

Purves D, Voyvodic JT (1987) Imaging mammalian nerve cells and their connections over time in living animals. Trends Neurosci 10: 398-403.

Purves D, Hadley RD, Voyvodic J (1986) Dynamic changes in the dendritic geometry of individual neurons visualized over periods of up to three months in the superior cervical ganglion of living mice. J Neurosci 6:1051-1060.

Purves D, Voyvodic JT, Magrassi L, Yawo H (1987) Visualization of synapses over time in living animals. Science 238:1 122-1 126.

Rakic P, Bourgeois J-P, Eckenhoff ME, Zecevic N, Goldman-Rakic PS (1986) Concurrent overproduction of synapses in diverse regions of the primate cerebral cortex. Science 232:232-235.

Ramón y Cajal S (1890) Origen y terminación de las fibras nerviosas olfatorias. Gaceta Sanit Barcelona, pp 133-139, 174-181, 206-212.

Rice FL, Van der Loos H (1977) Development of the barrels and barrel field in the somatosensory cortex of the mouse. J Comp Neurol 171:545-560.

Royet JP, Souchier C, Jourdan F, Ploye H (1988) Morphometric study of the glomerular population in the mouse olfactory bulb: numerical density and size and size distribution along the rostrocaudal axis. $J$ Comp Neurol 270:559-568.

Simons DJ, Woolsey TA (1984) Morphology of Golgi-Cox-impregnated barrel neurons in rat SmI cortex. J Comp Neurol 230:119-132.

Tootell RBH, Hamilton AL, Silverman MS (1985) Topography of cytochrome oxidase activity in owl monkey cortex. J Neurosci 5: 2786-2800.

Turner DL, Cepko CL (1987) A common progenitor for neurons and glia persists in rat retina late in development. Nature 328:131-136.

Van der Loos H (1976) Barreloids in mouse somatosensory thalamus. Neurosci Lett 2:1-6.

Voyvodic JT (1986) A general purpose image processing language (IMAGR) facilitates visualizing neuronal structures in fixed tissue and in vivo. Soc Neurosci Abstr 12:390.

Woolsey TA, Van der Loos H (1970) The structural organization of layer IV in the somatosensory region (SI) of mouse cercbral cortcx. The description of a cortical field composed of discrete cytoarchitectonic units. Brain Res 17:205-242.

Young JZ (1973) Memory as a selective process. In: Australian Academy of Science report: symposium on biological memory, pp 25-45. Canberra: Australian Academy of Science.

Young JZ (1979) Learning as a process of selection and amplification. J Roy Soc Med 72:801-814.

Young RW (1985) Cell differentiation in the retina of the mouse. Anat Rec 212:199-205. 